أثر المتغيرات المجتمعية والإسانية والعمرانية والتكنولوجية على المسكن الريفى بمحافظة الغربية سمية احمد حسن' ، ماجدة خضر جاب الله'، عفاف ميخائيل جبران'، مي احمد رأفت التطاوي

وذلك بقرية محلة منوف- محافظة الغربية، وقل تمثلت أساليب

تحليل البيانات الاحصائى في كل من التكرار والنسبة المئويسة -

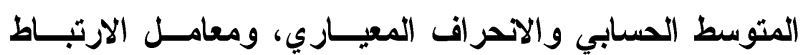

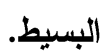

وأسفرت النتائج عن أن هناك علاقة إرتباطية معنوية عندـ

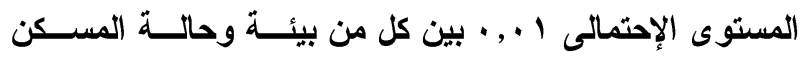

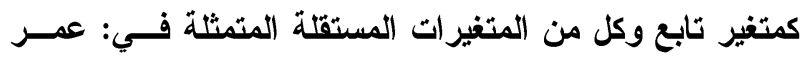

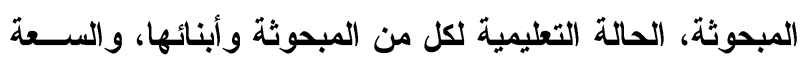
الحيازية الاجاجنة واستقلالية المعيثة.

كما تبين ذلك وجود تباين كبير بين المبحوثات فيما يتعــق بكل من المتغيرات المتصلة بكل من استقلالية المعيثة، الحيازة

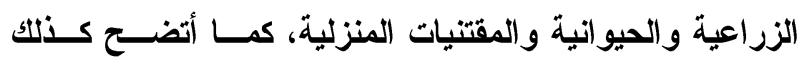

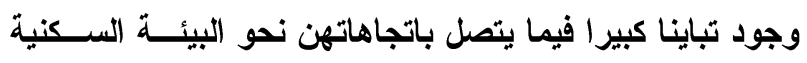

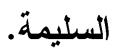

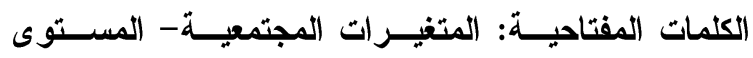
الاقتصادي والوضع البيئي

\section{المقدمة و المشكلة البحثية}

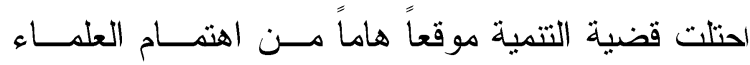

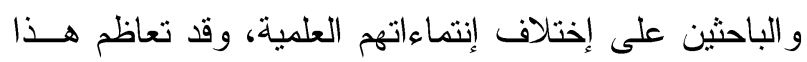

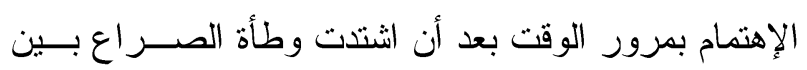

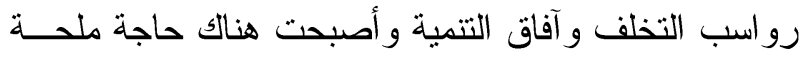
إلى تتمية القرية على وجه الخصوص من خلال إستر اتيجية فعاله للتتمية الريفية تمكن المجتمعات الريفية مـن إجتيــاز

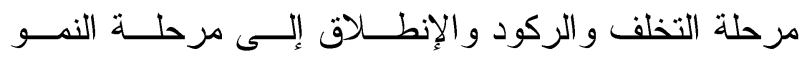
و الإرنقاء، وقد إندفعت البلدان النامية وبلدان العالم الثالـــث

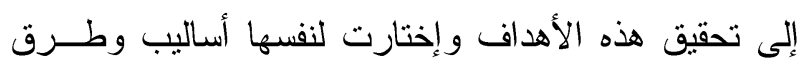
متباينة بهدف الإرتقاء بالمستوى الإقتصادي والإجتمـاعي

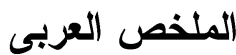

ويعتبر المسكن الريفـي مؤثــراً للمســتوى الاقتصــادي

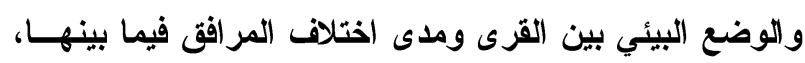
و والسلوك البيئي لسكان القرى من حيث حماية الموارد الأرضية وعدم التوسع في البناء على حساب الأرض الزراعية واستخدام

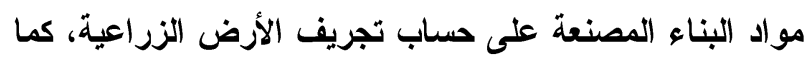
يثير إلى المستوى الصحي لأفراد الأسرة بحمايتهم من التلوث التهاث

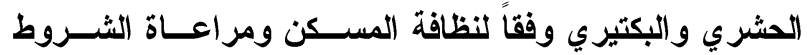

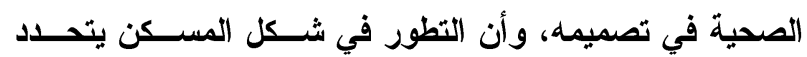
بموقف الإسان الذي يختلف باختلاف الحضارة التي ينتمي إليها

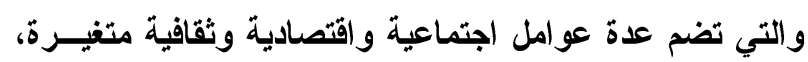
كما أن المسكن بثكله وتصميمه يمثل نمط الحياة الاجتماعيـة

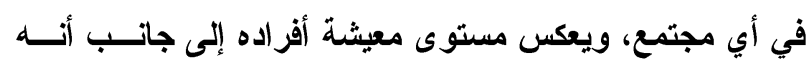
يعبر تعبيراً مؤشر اعن ونكن عاداته، وتقاليده.

و إذا كان المسكن الملام صحياً واجتماعيا واقتصاديا لفئات مختلفة من الأفراد أمراً صعباً في المدينة فإنه في الريف يزداد الدياد

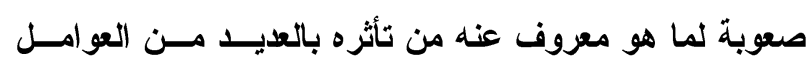

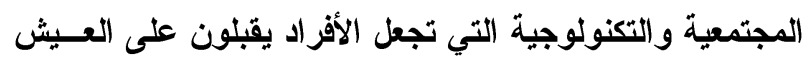

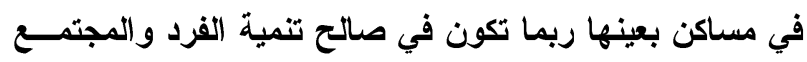
وربما لا تكون في صالحهما. وقد استهاف هذا البحث بصفة رئيسية دراسـة والتعـرف

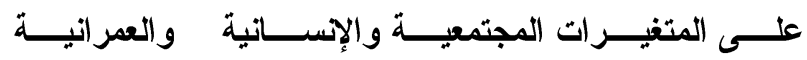
و التكنولوجية المؤثرة على مساكن الريفيين بإحدى قرى مركـز طنطا بمحافظة الغربية.

هذا وقد تم تجميع البياتات البحثيــة باســتخدام اســتمارة

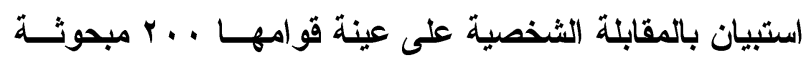

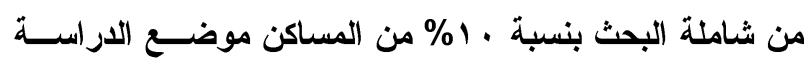

'قنسم الاقتصاد المنزلي- جامعة الاسكندرية

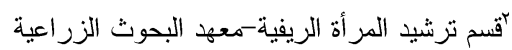

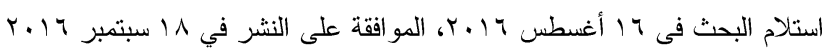




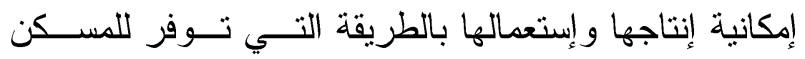

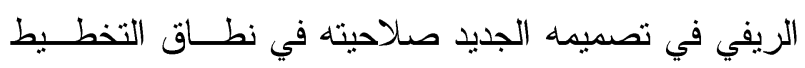

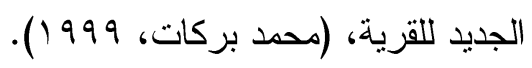

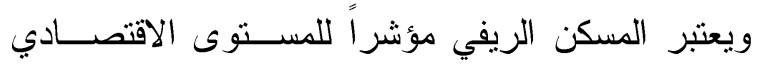

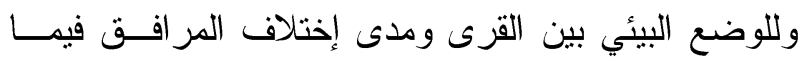
بينها، و السلوك البيئي لسكان القرى من حيث حماية المو ارد

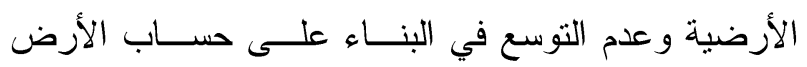

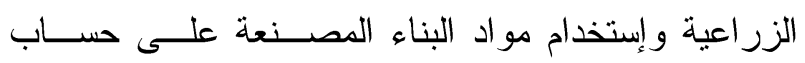

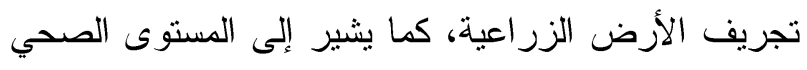

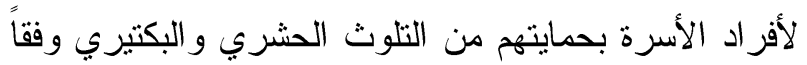
لنظافة المسكن ومر اعاة الثروط الصــية فــي تصــميمه

$$
\text { (مصطفى الحفناوي، •9191). }
$$

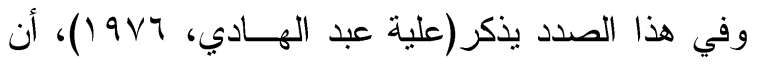
التطور في شكل المسكن يتحدد بموقف الإنسان الذي يختلف

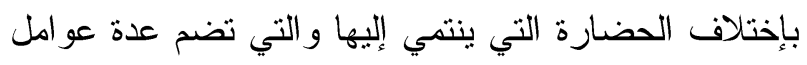
إجتماعية و إقتصادية وثقافية متغيرة، كما أن المسكن بشكله

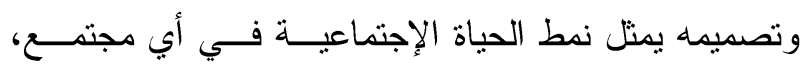
ويعكس مستوى معيشة أفر اده إلى جانب أنه يعبــر تعبيــراً مباثراً عن عاداته، وتقاليده.

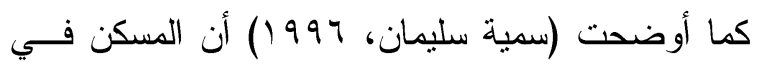
نظور مستمر مع مرور الزمن حسب احتياجات أفراد العائلة

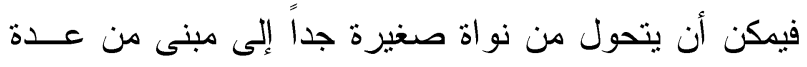

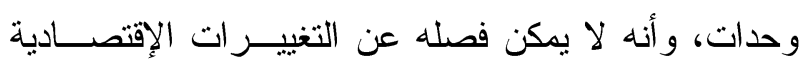

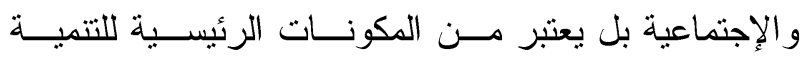

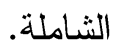
ونظر اً لأن سكان المناطق الريفية يمثلون (r؟٪\%) مــن

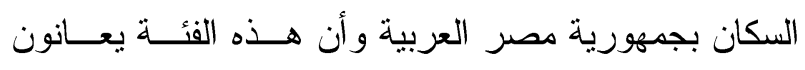
وقراهم من إهمال في كافة إحتياجاتهم حيث ما زالت منـلـل

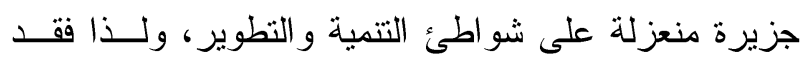
تنثلت مشكلة هذا البحث في التساؤلات التالية:
و الثقافي و الســكني للمجتمعسـات الريفية،(ســـير قنـديل، .$(1997$ ويمثل الإسكان جانباً رئيسياً من ثقافة أي مجتمع فهـو

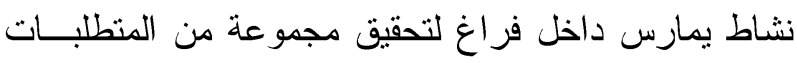

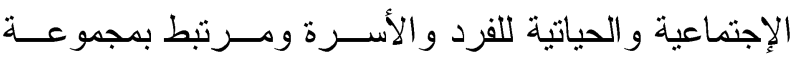
العمليات الهندسية مسن تخطــيط وبنــاء و إدارة وصـيـانة و إعتبار ات إقتصادية إجتماعية وسياسية ونفسيه بهذف إيجاد

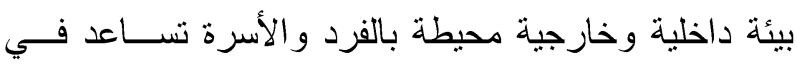

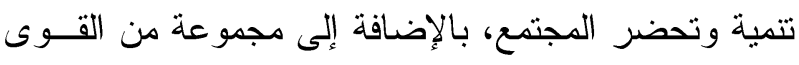

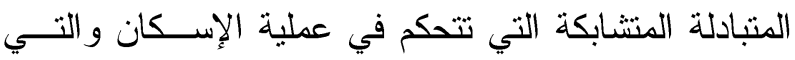

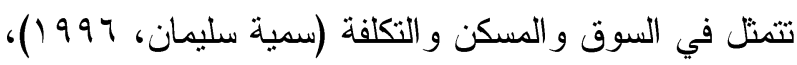

(هثام الثيمي، (1999 ).

وتعتبر الموارد البشرية هي العامــل العــاكم والفعــال

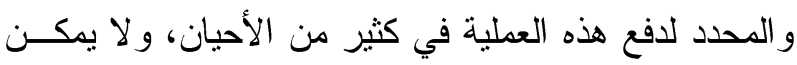

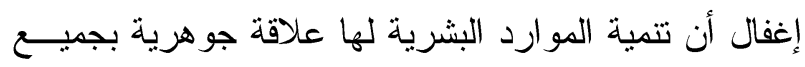

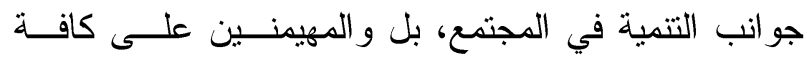
العمليات الإنتاجية، و المسيطرة على كافة المو ارد المتاحسة،

$$
\text { (زينب عبد الحميد، . . ب). }
$$

وتتضـح أهمية الأسرة في أنها تعكس مختلف الظـــــاهر

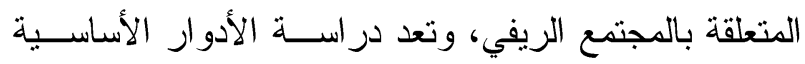

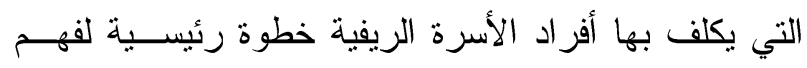

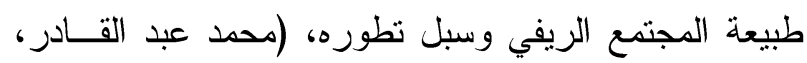
.$(Y .$.

وتعد مشكلة الإسكان الريفي من أهم النواحي التي تهتم

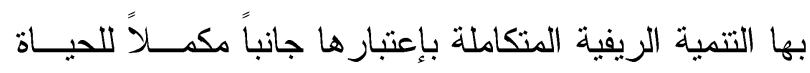

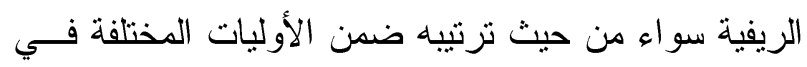

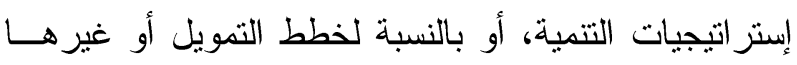

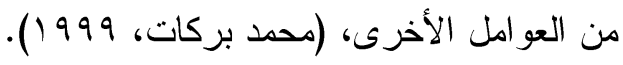
ويعتمد الإسكان الريفي من جهة على الاتجاه التخطيطي

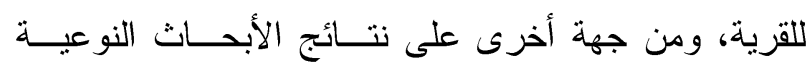

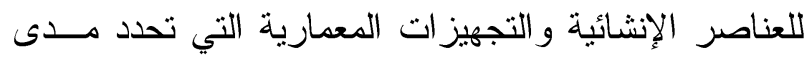




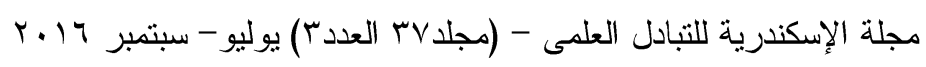

\section{الأهمية النظرية والتطبيقية للبحث:}

تتمثل أهمية هذا البحث في حث المسئولين و الباحثين على ضرورة وضع القرية المصرية علي خريطة التنمية

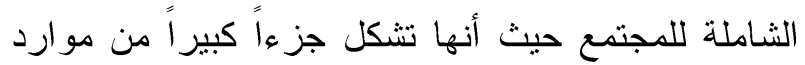
المجتمع المادية و البشــرية، ولفــت نظـــر المســـولين و الجهات المعنية إلى أهمية البحوث و الدر اســات التـي تتناول الأسرة الريفية بصفة عامة والمرأة الريفية بصفة ولهية

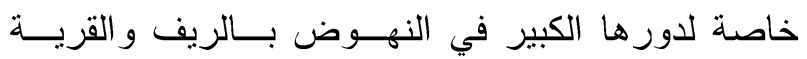
المصرية. هذا إلى جانب الأهمية العلمية و التي تتمثل في

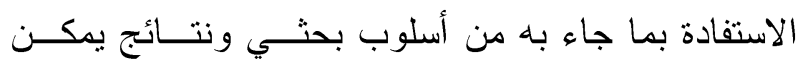

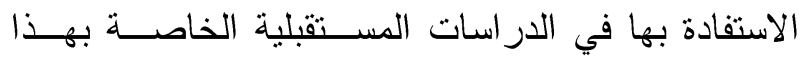

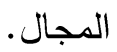

\section{الأسلوب البحثي}

\section{المفاهيم و التعريفات الإجرائية:}

من المسلم به أن تحديد المفاهيم المختلفـــة و التعريفــات للمصطلحات المختلفة يعد ضروري لتحقيق الإدر الك والفهم

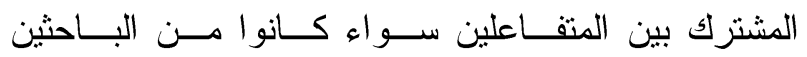
أو التطبيقيين أوغيرهم، ويطلــق علـى أي مــن المفــاهيم

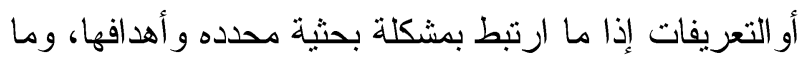

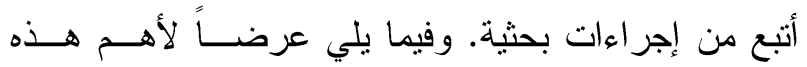
المفاهيم و التعريفات المختلفة الواردة بهذه الدر اسة: 1- الانفتاح الحضاري: الانفتاح مرتبط في العمق بمفهـوم الحرية، وهو ظاهرة إنسانية اجتماعية تخضع للعديد من المعايير في تعريفها وحدها، ومجالاتها، وكل ما يرتبط بها، حيث عبر عنه بمدى تردد المبحوثة على كل مـن

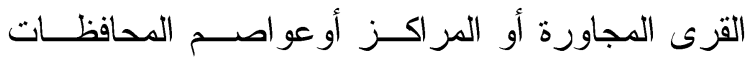

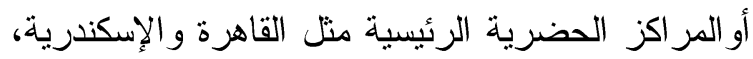

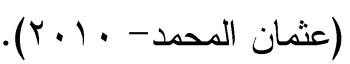

r - المصادر المرجعية: يقصد بها في هـذذا البحــث عـدد

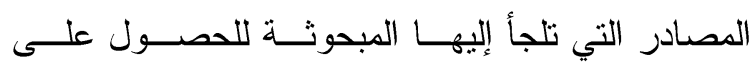

أ- ماهي المتغير ات التي تؤثر على عمارة القريــة وحالـــة

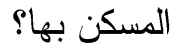

ب- ماهي المشاكل الحالية التي تو اجه تطوير المسكن بها؟ جـ- ماهي الظروف الإجماعية و الإقتصـــادية والإنســانية و الإتصالية المؤثرة على الوضع الحالى للقرية؟

\section{الأهداف البحثية}

إستهدف هذا البحث بصفة رئيسية در اسة و التعرف على

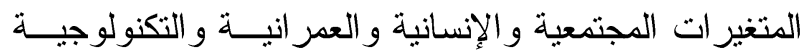
المؤثرة على مساكن الريفيين بقرية محلة منــوف مركــز طنطا بمحافظة الغربية وذللك من خلال الأهداف الفرعيـة

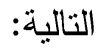
ا - دراسة المتغير ات المجتمعية بالقرية موضـع الدراســة

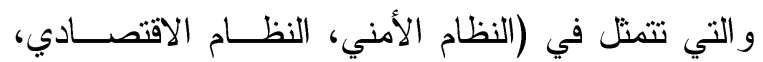
النظام التعليمي، خدمات البنية الأساسية). r- - در اسة المتغيرات الإنسانية بالقرية موضــع الدراســـة

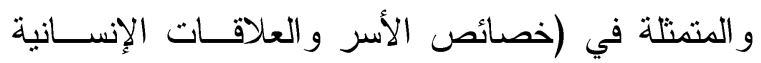
و النمط البنائي للأسر موضع الدراسة. r- در اسة المتغيرات العمر انية بالقرية موضـــع الدراســة

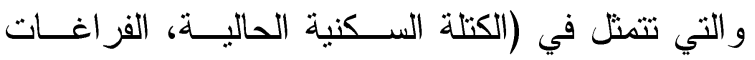
الموجودة داخل الكتلة السكنية، الإمتداد الرأسي للمساكن

$$
\text { بالقرية، الإمتداد العشوائي). }
$$

عـ - در اسة المتغيرات التكنولوجية بالقرية موضع الدراسة و المتمثلة في (مواد البناء و التشطيبات المستخدمة، آليات البناء للمساكن، إمدادات المياه و الطاقة وطرق التخلص

$$
\text { من المخلفات الحقلية والإنسانية). }
$$

0ـ - در اسة التصميم الداخلى وحالة المسكن للإسر موضع

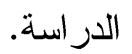
7- در اسة العلاقات الإحصـائية بين المتغيــرات المســتقلة و التابعة للبحث. 
- V تكنولوجيا البناء: هي حلقة ربط بعض فروع الهندسـة

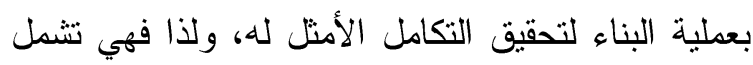
التصميم الإنشائي، و البيئي، وطرق البناء الــذي يحقـق

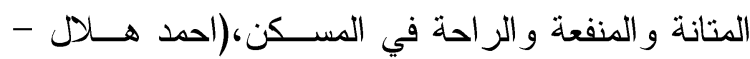
.$(1994$ ^-المسكن: المسكن هو المأوى و الفراغ الو اقي الذي يقـي

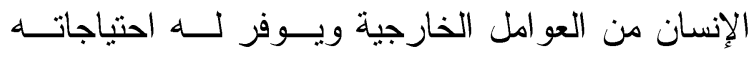

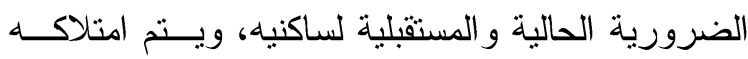
بأقل التكاليف وبأفضل جودة(حسن الفارس- 9 . . r). 9 - المسكن الريفي: هو نمط من أنـــواع المســاكن التـي

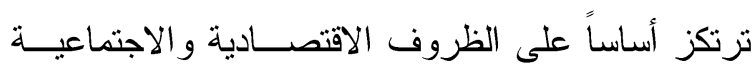

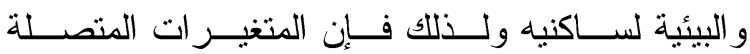

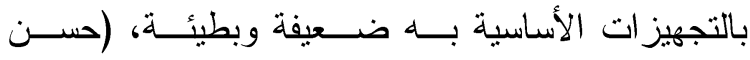

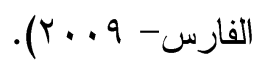

ويعرف المسكن الريفي في هذا البحث على أنه: مسكن

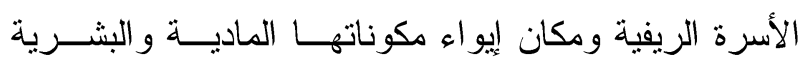

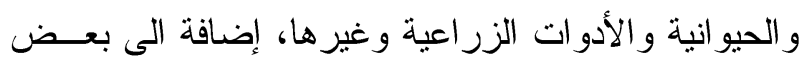

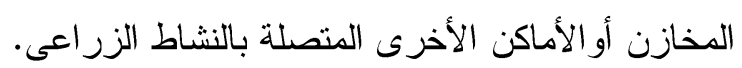
• 1 - التصميم الااخلي: هو فن معالجة الأماكن و المساحات

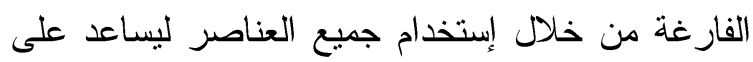

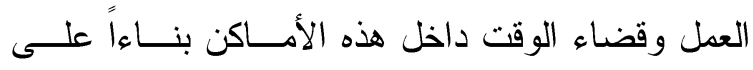
مو اصفات المكان من حيث المساحات الفارغة وشكلها،

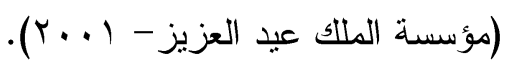

و المقصود به فى هذا البحث: مساحة وشكل و عدد وحالة الفر اغات الداخلية للمسكن و إستخدامات المر افق الخاصة به.

$$
\text { المتغير ات البحثية: }
$$

يتتاول هذا الجزء عرضاً للمتغيرات البحثية التـي تـــ تحديدها و أبعاد قياسها في ضو هء أهداف البحث وهي: أ المتغيرات المستقلة: و التي تمثلت في كل من:
المعلومات (الأفكار و المعارف) أو الإجابة عن التساؤلات أوحل لمشكلات خاصة بها أوبالشئون الأسرية. r- المشاركة الاجتماعية: الدور الذي يلعبه الأفــراد فــي

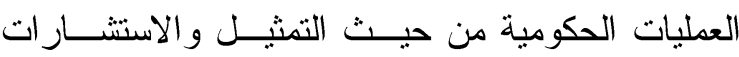
و الاشتر الك في عمليات التتمية وهى إسهام اكبر قدر من

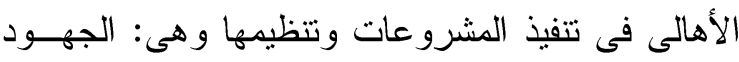

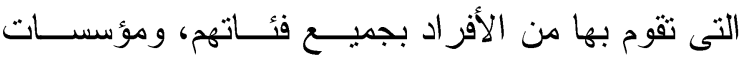

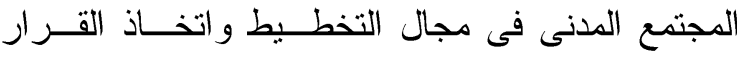

$$
\text { و التنفيذ،(هناء سعد - •. • (ץ). }
$$

ويقصد بها فى هذا البحث: مدى إسهام المبحوثــة فـى

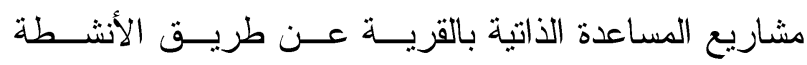
و الو اجبات الإجتماعية المختلفة.

צ - التجمع العمراني الريفي: هو التجمع العمراني لســكان الريف الذي تتركز فيه مساكنهم، وخدماتهم الإجتماعيــة بصورة دائمة في منطقــة جغر افيــة محــددة، (ياســـر

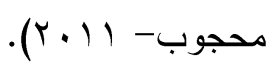

ويقصد به في نفس هذا البحث نفس المفهوم السابق. ه- البيئة العمرانية: هي نتاج علاقة الإنسان بالبيئة التـي يعيش فيها سواء علاقة مباشرة أو غير مباشرة، أبي هي هي النسيج المعبر عن تفاعل الإنسان مع بيئته بهدف إثباع

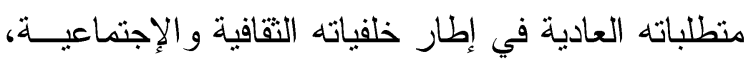

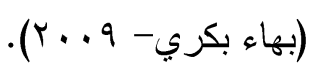

7 -التغير في البيئة العمر انية: هو حدوث تغيــرات فيهـــا تتعارض مع استمر ارية النمط العمراني القديم

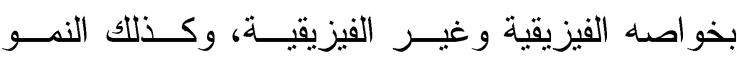

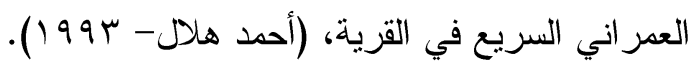
ويقصد به في هذا البحث التغيرات الحادثة فـي النمــو العمر اني من حيث الشكل العام وكتلة المساكن، و الخــدمات و المر افق و المؤسسات داخل القرية. 


$$
\text { مجلة الإسكندرية للتبادل العلمى - (مجلد Tr العددץ) يوليو - سبتمبر Y } 17
$$

سن المبحوثة الحالـــة التعليميــة للمبحوثــة الحالـــة

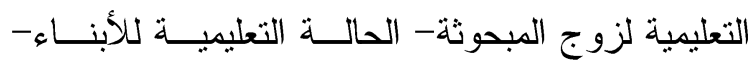
الاخل السنوي- الحيازة الزر اعية- الحيازة الحيوانية-

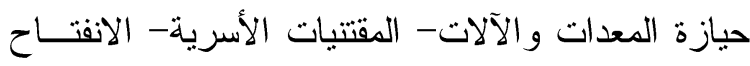
الحضاري- المصادر المرجعية- المشاركة الاجتماعية

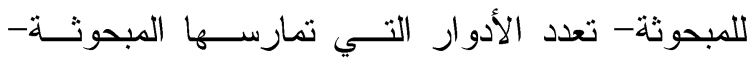

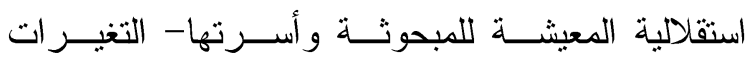
العمر انية و التكنولوجية بالقرية موضع الدراســة وبــين وكين حالة وبيئة المسكن كمتغير تابع. منطقة البحث: تم إختبار مركز طنطا مــن ضـــمن المر اكــز التابعــة

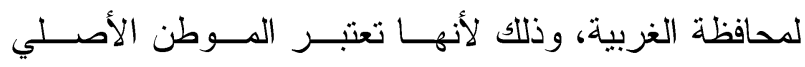
للباحثة، الأمر الذي يسهل عليها الحصول على بيانات أكثر دقة، كما أنها تتناسب وظروف الباحثة خاصة في مرحلــة تجميع البيانات الخاصة بالدر اسة و البحث. هذا وقد تم إختبار قرية محلة منوف عمدياً من القــرى

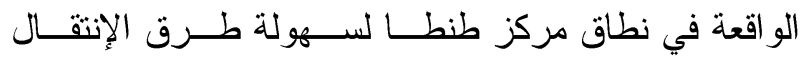
المختلفة إليها الأمر الذي ييسر عملية جمع البيانات.

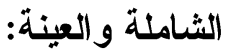

تتطوي شاملة هذا البحث على جميع المساكن بقريــة

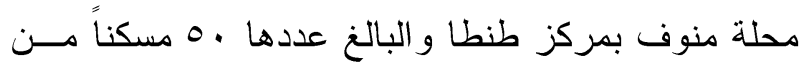

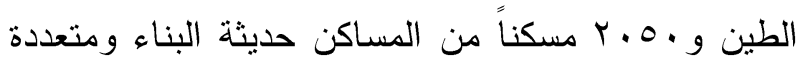

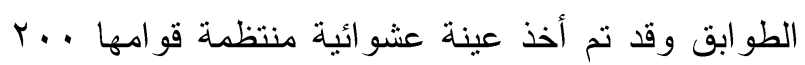
مسكناً بنسبة · (1\% من الشاملة لإجر اء هذه الدراسة وقد استبعدت عشرة استمار ات غير كاملة.

\section{أسلوب جمع البيانات}

وبناءاً على ذلك تم تصـــيم إســـمارة البحــث و التـي تضمنت مجموعة من الأسئلة تحت عدد من الأقسام علــى

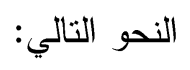

1 - البيانات الخاصة بالمتغير ات الإجتماعية و الشخصية.
1 - المتغير ات الخاصـــة بالجو انــب الشخصــية الإنســانية

و المتمتلة في كل من: ( الســن - الحالـــة التعليميــة -

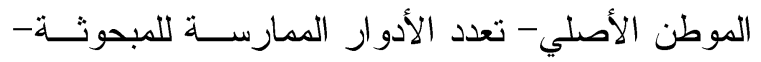

(إستقلالية المعيشة).

r - المتغير ات الخاصة بالجو انــب الاقتصـــادية و المتمثلـــة

في:(الدخل الأسري و الشخصي- الحيـــازة الزراعيــة

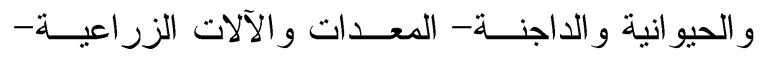

المقتنيات الأسرية بكل أنو اعها).

r- المتغير ات الخاصة بالاتصـــال و الانفتــاح الحضـــاري

و المتمثلة في:(ممارسة الأمور الحياتية- التـردد علــى

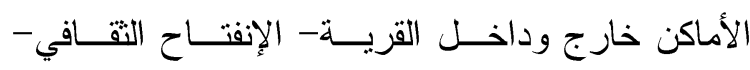

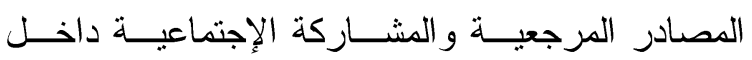

(القرية).

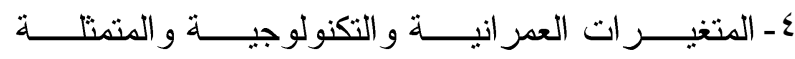

في:(التغيرات الحادثة في شكل القرية عمر انية و إنثائية وتكنولوجية).

ب المتغير ات التابعة: تمثلت في المتغير التـابع و الخــاص بحالة وبيئة المسكن من جميع الجوانب الماديــة وغيــر المادية.

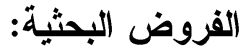

المقصود بالفرض العلمي حل مقتر ح أوتقســير مبــئي لظاهرة من الظواهر، وتظل صحة هذا الحــل أو التفسـير

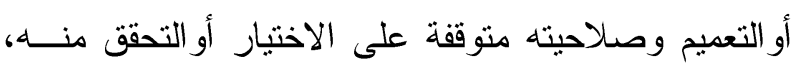
ويحدد الفرص الصغرى وصف للعلاقة السببية بين متغيرين أوعاملين أحدهما هو المتغير المستقل، والآخر هو المتغيـر

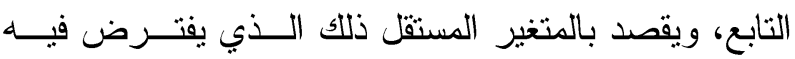

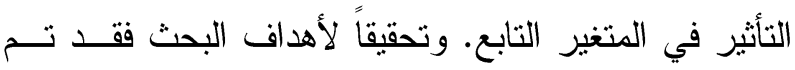
صياغة الفروض البحثية فى صورتها النظرية على النحــو

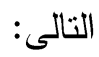
1- توجد علاقة إرتباطيه معنوية بين كل مــن المتغيــرات المستقلة الكمية للمبحوثات كل على حدى والمتمثلة في: 
حياته، ولقد أشنار ات العديد من الدراسات إلى أن كبــار

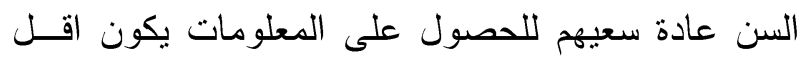

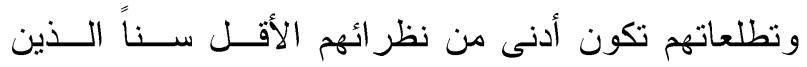
يتسمون بالمرونة و التفتح، (صفاء صالح- ؟ ؟ 99 (1). ولقد أوضحت النتائج تدني نسبة أعمار الأزواج فـي

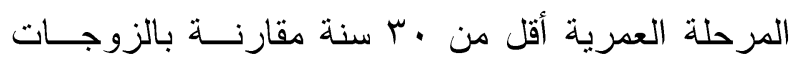

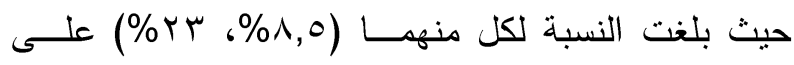
التو الي، في حـين تعادلــت نســبة كــلاً مــن الأزواج و الزوجات في المرحلة العمرية التي تراوحت بين (• (

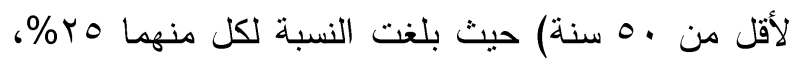
وقد بلغت النسبة عند المرحلة العمرية .0 سنة فــأكثر $\cdot(\% \leqslant r, 0)$ هذا وقد تبين من الدراسة أن القيم الرقمية المعبــرة

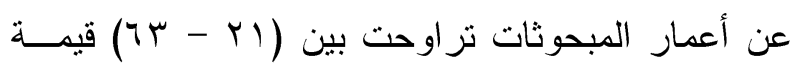

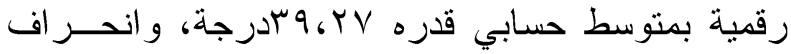
معياري ؟9، • ادرجة، ومعامل اختلاف 9.9.9 و هذا

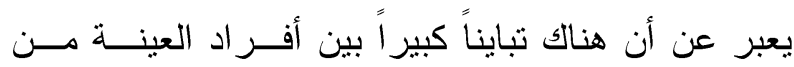
المبحوثات

\section{r - ب الحالة التعليمبة:}

إن للتعليم أثزه الكبير على أفاق المعرفة المتعـددة، وفرص الإطلاع على مصادر التقافــة والتوعيــة، ولا يمكن إغفال أن المر أة تكتسب من خلال التعليم قـدر ات معرفية تمكنها من إستجلاء الحقائق وفهم الأمور بدقـــة

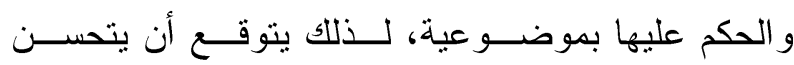
المستوى المعرفي لها بـارتفاع الحالـــة التعليميـــة لهــــا،

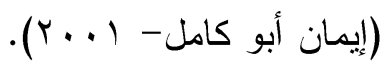
ولقد أوضحت النتائج البحثية تفاوت نسبة الزوجــات المبحوثات الأميات بالنسبة لأزواجهن حيث بلغت النسبة

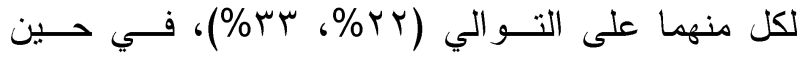

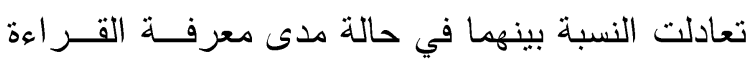
و الكتابة حيث بلغت(؟\%) لكل منهما، وتقاربت النســبة r- البيانات الخاصة بالجو انب الإقتصـادية.

r- البيانات الخاصـــة بالإتصـــال والانفتــاح الحضـــاري و المصادر المرجعية.

عـ البيانات الخاصة بــالتغيرات العمر انيـــة و التكنولوجيــة بالقرية موضع الدر اسة.

0ـ البيانات الخاصة بالجو انب الخاصة بحالة المسكن و البيئة السكنية و التصميم الداخلي. هذا وقد تم إختبار الإستمارة بإجراء Pre-Test عـــى عينة من المساكن و المبحوثات قو امها ( • r) إستمارة تم دن خلالها حذف و إضافة وتتقيح إستمارة الإستبيان في صورتها النهائية.

\section{أسلوب تحليل البيانات البحثية:} مر تحليل البيانات البحثية بعدة مر احل تمهيدية بداية من المر اجعة لكل استمارة عقب استيفائها، تم تفريغ البيانــات،

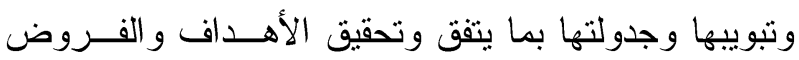
البحثية التي تختبر ها الدر اسة. هذا وقد تم الإستعانة بعدد مــن الأســاليب الإحصــائية تمثلت في النسب المئوية، و المتوسط الحسابي، و التكرارات، و الإنحر اف المعياري ومعامل الإختلاف ومعامل الارتبــاط

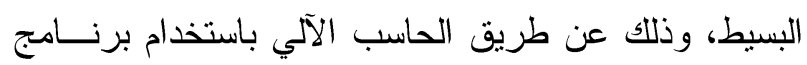
."SPSS"

\section{النتائج البحثية ومناقشتها}

النتائج البحثية المتصلة بالخصائص الإنسانية والاقتصادية والاجتماعية و الاتصالية أولاً: الخصائص الإنسانية للمبحوثات:

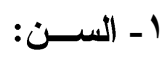

لا يمكن إغفال أن السن له صلة وثيقة بالخبرة التـي يحصدها الإنسان على مــدى ســنين حياتــه، وكـذللك المعارف و المعلومات التي تكون البنيان المعرفـي لــه، كمحصلة لسعيه في طلب المعلومات وتحسـين ظــروف لهـون 


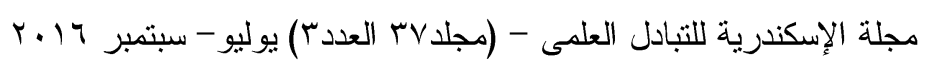

في شتى مناحي الحياة، خاصة في ظل ما ينسم به الريف المصري من أرتفاع نسبة الأمية بين الريفيات. هذا وقد تبين من الدراسة أن القيم الرقمية المعبـرة

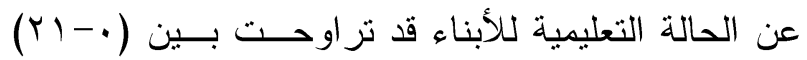
قيمة رقمية بمتوسط حســابي ع ا , لادرجــة، و انحسـر اف

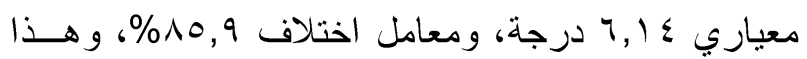
يعبر عن مدى ارتفاع نسبة التباين بين الحالة التعليميــة

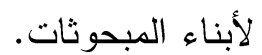

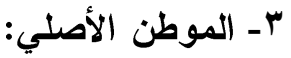

اتضـح من النتائج البحثية أن هناك تقارب كبير جــــاً فيما يتعلق بالموطن الأصلي للمبحوثات و أزو اجهـن

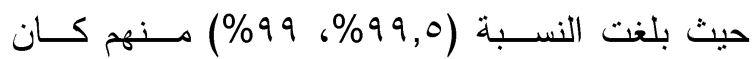
موطنهم الأصلي ريفي أما النسبة الضــئيلة المتبقيــة

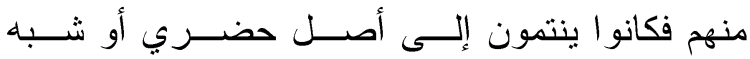
حضري (مر اكز)، وهذه النتيجة قد تؤدي إلى أنهـــ إنـ

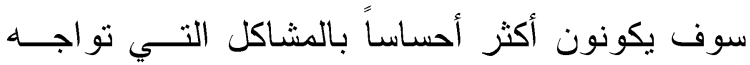
بيئتهم و أكثر إدر اكاً للسعي لإيجاد الحلول المناســبة بـونة لها، وكذلك تساعد على التعاون بينهخ وبين بعض. ع - تعدد الأدوار الممارسة:

إن ممارسة المرأة الريفية لعدد من الأدوار من شأنه

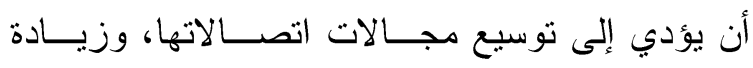
التعرض للمعارف و المعلومات سو اء بصفة شخصية،

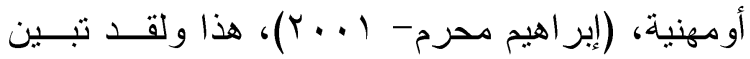

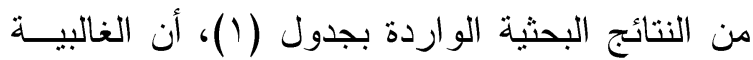
العظمى من المبحوثــات ربـــات بيــوت متفرغــــات (\%^9,0)، و أن نسبة من تقمن بأدوار في الأعمــال

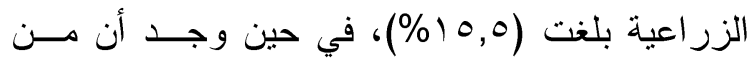

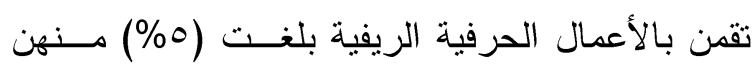

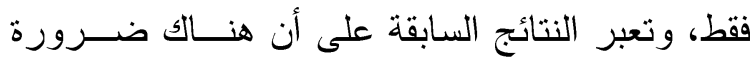

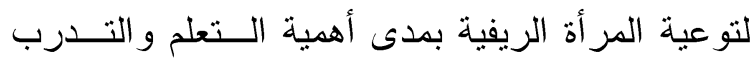
على الحرف الريفية كمصدر للاخل وتنمية المجتمــع
بينهما في حالة الحاصلين على المرحلة الثانوية و التعليم

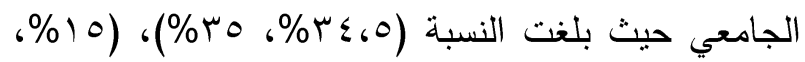
• (\%) لكل منهما بالمرحلتين على التو الي.

ومن النتائج السابقة يتضح ضرورة العمل على زيادة جهد المجتمع المدني و الحكومة في العمل علــى محــو الأمية عن طريق برامج مطورة لمحو الأمية و التوعيـة بأهمية التعليم لكل فئات المجتمع. هذا وقد تبين من الدراسة كــذلك أن القــيم الرقميـــة المعبرة عن الحالة التعليمية للمبحوثات قد تراوحت بـين

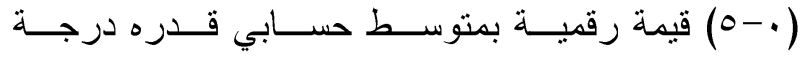

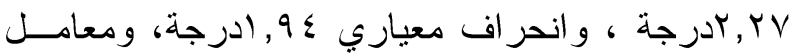

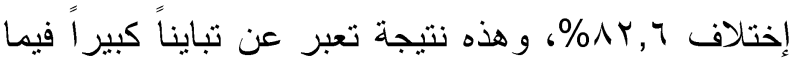
يتعلق بالناحية التعليمية بين المبحوثات كما تبــين مــن الدر اسـة كذلك أن الدرجة الرقمية المعبرة عــن الحالـــة التعليمية لأزواج المبحوثات نراوحت بين ( •-0) قيمــة رقمية بمتوسط حسابي YoOV درجة، و إنحر اف معياري

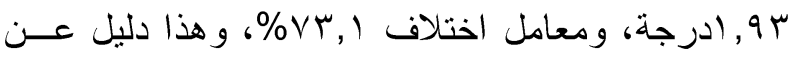
مدى التباين بين أزواج المبحوثات فيما يتعلق بالناحيـة

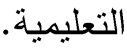
وفيما يتعلق بالحالة التعليمية للأبناء فقد تبـين مــن النتائج أن ( • ب\%) من أبناء المبحوثات دون سن الإلزام

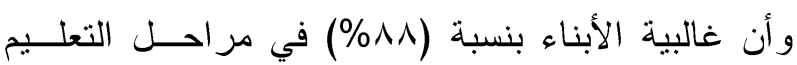
الثانوي المختلفة، وتدنت نسبة الأبناء ممن يقر أ ويكتـبـ حيث بلغت نسبتهم (r\%) فقط من جملة عدد الأبناء. هذا وتعبر النتائج السابقة عـن إهتمــام المبحوثـات

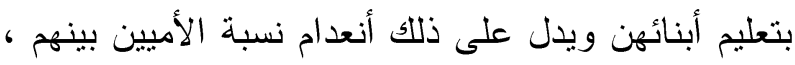
وهذا يؤكد ما ذكره كلاً من (عبد الحليم مزربان، عبــد الصبور عبد الوهاب- 997 ())، من أن تعليم الأبناء يعد هئم عامل حيوي و هام يتوقع أن يكون له تأثير إيجابي علــى مستوى معارف المبحوثة بأعتبار الأبناء مصدر مرجعي خصب تستقي منه غالبية الريفيات معارفهن ومعلوماتهن 
وبالتالي يمكنها ممارسة حياتها وقرار اتها بطريقة أكثـر

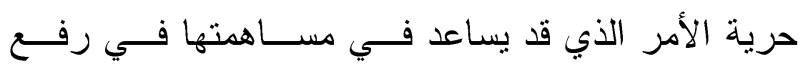
مستو اها الاقتصادي وتنمية مجتمعها المحلي. جدول r. توزيع المبحوثات وفقاً لمدى استقلالية المعيشة

\begin{tabular}{|c|c|c|}
\hline$\%$ & العدد & استقلالالية المعيشة \\
\hline Vo & 10. & مستقلة \\
\hline r & $\varepsilon$ & مع أهلها \\
\hline$r$ & $\sum 7$ & مع أهل الزو ج \\
\hline $1 \ldots$ & r... & المجموع \\
\hline
\end{tabular}

هذا وقد تبين من الدراسة كـــلك أن القـيم الرقميــة المعبرة عن مدى استقلالية المعيشة الخاصة بالمبحوثات

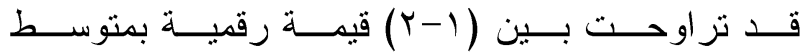

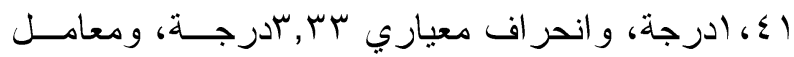

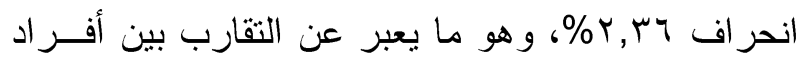
العينة فيما يتصل بإستقلالية المعيشة.

ثانياً: الخصائص الاقتصادية:

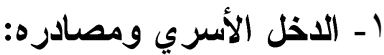

لا شك أن الدخل يؤثر في مختلف السلوك البشــري، ويعتبر مؤشراً هاماً لإمكانيــة الثـــــاء، و الوســائل

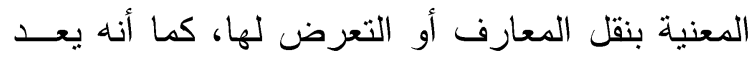

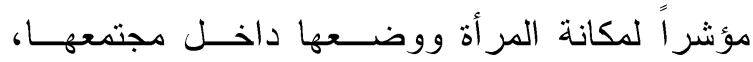

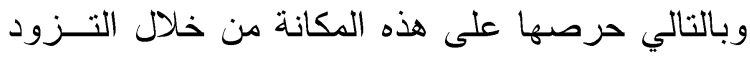

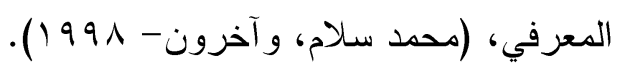
وتثير النتائج البحثية إلى أن ما يعادل (؟ب\%) مسن

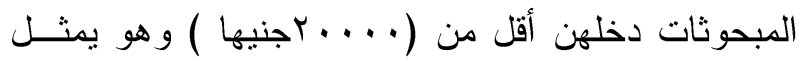
الغالبية بالعينة، وأن ما يعادل (, به\%) من أفراد العينة

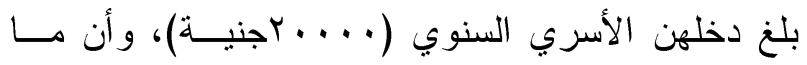

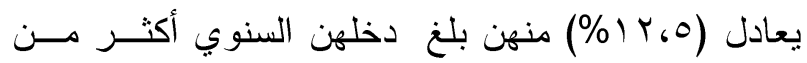
. $0 . .$.

هذا وقد تبين من الدراسة كـــلك أن القـيم الرقميــة المعبرة عن الدخل ألأسري للمبحوثات قد تراوحت بـين الدين

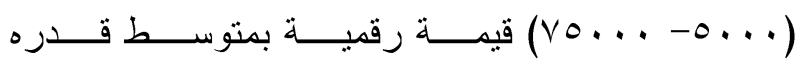

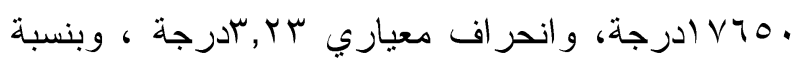

وشغل أوقات الفر اغ عن طريق الصناعات الحرفيــة متتاهية الصغر داخل مساكنهن خاصة وأن غالبيتهن لا يعملن ومتفر غات.

جدول اـ توزيع المبحوثات وفقـاً لطبيعـة الأدوار التــي

\begin{tabular}{|c|c|c|}
\hline$\%$ & التكرار & الأدوار \\
\hline 19,0 & 189 & بة بيت متفرغة \\
\hline 10,0 & rI & الأعمال الزراعية \\
\hline $1 \cdot, 0$ & YI & موظفة حكومية \\
\hline $\bar{v}$ & $1 \varepsilon$ & لأعمال التجارية \\
\hline 0 & 1. & الأعمال الحرفية \\
\hline
\end{tabular}

هذا وقد تبين من الدراسة كـــللك أن القـيم الرقميـة المعبرة عن تعدد الأدوار بالنسبة للمبحوثات أفراد العينة

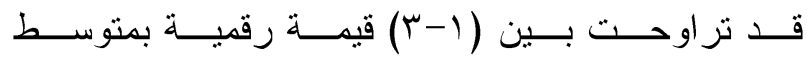

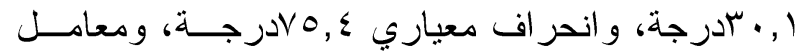
إختلاف 9,9 \% \%، و هذه النتيجة تعبر عن مدى التبــاين

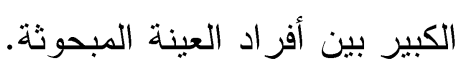

\section{هـ استقلالية المعيثة:}

تشير الدراسات إلى أن إقامة المرأة في أسرة بسيطة

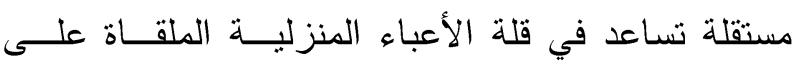

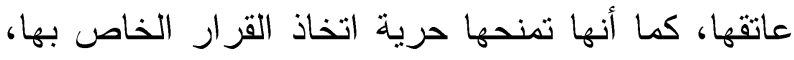

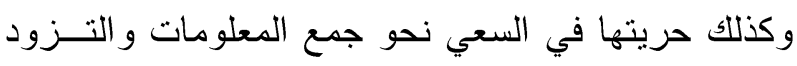

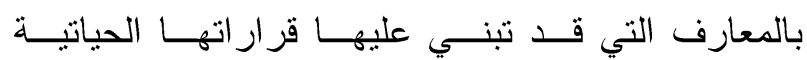
و الأسرية، وذلك بالمقارنة مع تلكك التي تقيم فــي أســرة

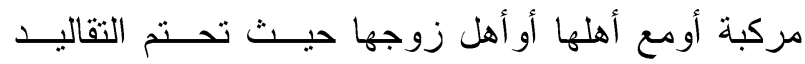
الريفية الاستعانة برأي الآخرين من الكبار و الانصــياع الفياع

$$
\text { لهم، (فؤ اد سليم- } 997 \text { (1) ). }
$$

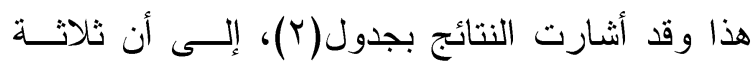

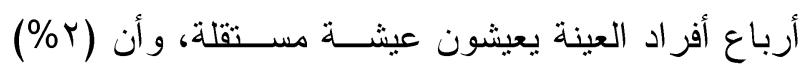

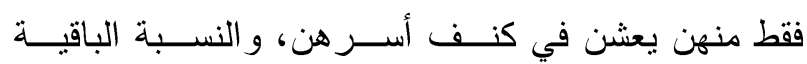

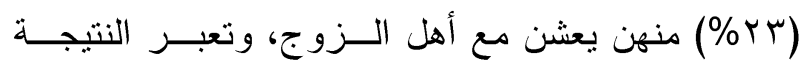

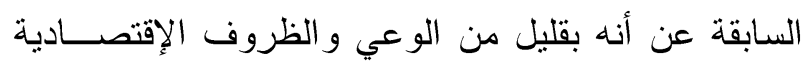
للريفيين يمكن أن تزداد نسبة الإستقلالية للمر أة الريفيــة 
مجلة الإسكندرية للتبادل العلمى - (مجلد Tr العددץ) يوليو - سبتمبر Y 17

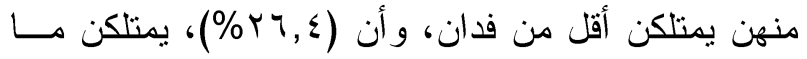

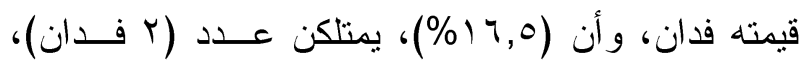
و النسبة الباقية (سr\%)، يمتلكن ما قيمته ثلاتــة أفدنــة فأكثر، و هذه النتيجة تعبر عـن صــغر حجـــ الحيــازة الزر اعية لدى غالبية المبحوثات ممن يمـتلكن أر اضــي فئي زر اعية خاصة بأسر هن.

جدول ع. توزيع المبحوثات ممن يمتلكن أراضي زراعيــة بحوزتهم وفقاً للمساحة (السعة)

\begin{tabular}{|c|c|c|}
\hline$\%$ & العدد & السعة بالفدان \\
\hline$r \varepsilon, 1$ & M & أقل من فدان \\
\hline$Y \Psi, \Sigma$ & $r \varepsilon$ & فدان \\
\hline 17,0 & 10 & r فدان \\
\hline rT & $r$ & r فأكثر \\
\hline $1 \ldots$ & 91 & المجمو ع \\
\hline
\end{tabular}

هذا وقد تبين من الدراسة كذلك أن القيم الرقمية المعبرة عن الحيازة الزراعية لأسر المبحوثات قد تزاوحست بــين

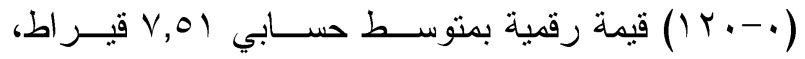

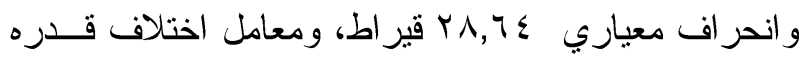

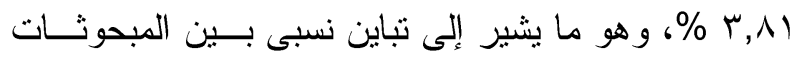
فيما يتعلق بامتلاكهن للأر اضي الزر اعية.

\section{ب الحيازة الحيو انية:}

تمثل الحيوانات المزرعية موارد إنتـــاج حيويـــة لــدى الأسرة الريفية، فهي مصدر للغذاء و الأسددة، إضافة إلـى

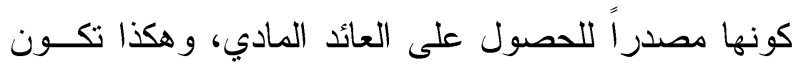

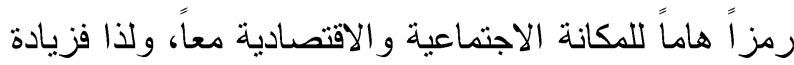

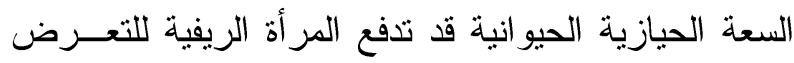
للمعارف المتعلقة برعاية الحيوان و الحفاظ عليــهـ وتـــــير

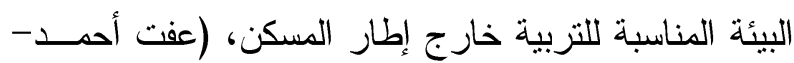

.$(199 \mathrm{~V}$

أثارت النتائج البحثية إلى أن هناك ما يعادل (ع ٪\%)،

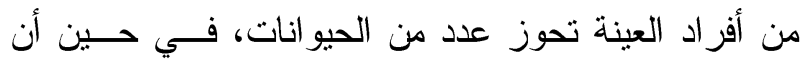

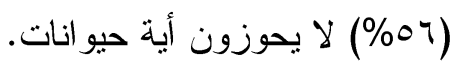

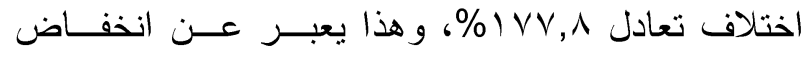

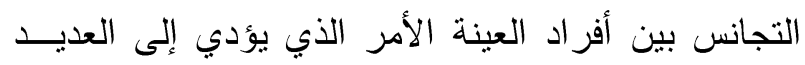
من السلبيات خاصة فيما يتصل بتلبية حاجاتهن المعيشية. و أما ما يتعلق بمصـادر الــدخل الأســري الســـوي للمبحوثات فقد اتضح من جدول (r)، أن الإنتاج النباتي

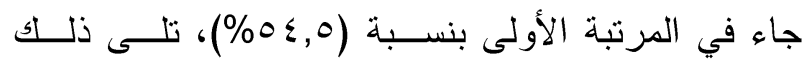
المرتب الحكومي بنسبة (ro\%))، وجاء النشاط التجاري

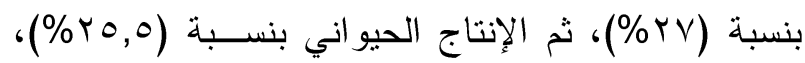

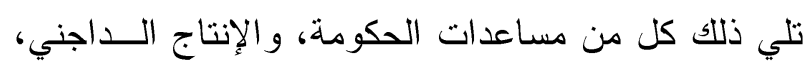

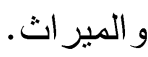
جدول r. توزيع المبحوثات وفقاً لمصادر الاخل الســنوي

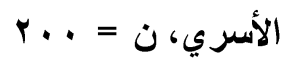

\begin{tabular}{|c|c|c|}
\hline$\%$ & التكر ار & المصادر \\
\hline $0 \leqslant, 0$ & 1.9 & الإنتاج النباتى \\
\hline OY & $1 . \varepsilon$ & مرتبات حكو مية \\
\hline TV & $0 \leqslant$ & نشاط تجاري \\
\hline Yo,0 & 01 & الإنتاج الحيو اني \\
\hline 11 & TY & مساعدات حكو مية \\
\hline 7,0 & $\pi$ & الإنتاج الداجنى \\
\hline 1,0 & $\mu$ & المير اث \\
\hline
\end{tabular}

r- العيازة: تعددت الحيــاز ات الخاصـــة بالمبحوثــات الريفيات حيث تبين أنها قد تنوعت على النحو التالي: الحيازة الزراعية: - الزية

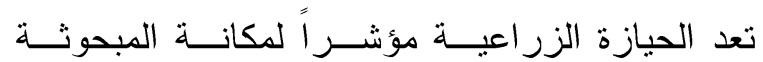
إجتماعياً داخل القرية وبين أقر انها، و لا شك أن المبحوثة هونة

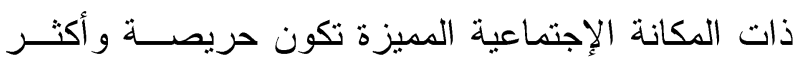
سعياً للتعـرض لمصــادر المعلومــات ســـواء العامــة أو المتعلقة بالحياة الأسرية وذلك حفاظاً على تلك المكانة،

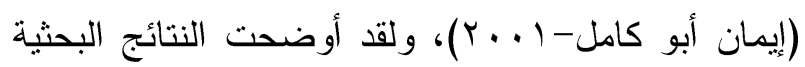
أن (0,0٪\%)، من المبحوثات أفر اد العينة تمتلك أسرهن

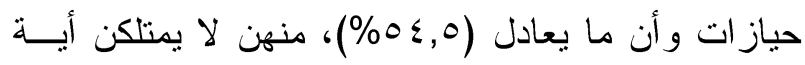

$$
\text { أر اضي زر اعية. }
$$

وبالتعرف على السعة الحيازية الزر اعية لمن يمتلكن فقد أوضحت النتائج الواردة بجدول (؟)، أن (1, §r\%) 
وبالسؤال عن نوعية الحبازة الاجنة لــــى أفــر اد العينة المبحوثة ممن يحوزون فقد ثمثلت في الــدواجن

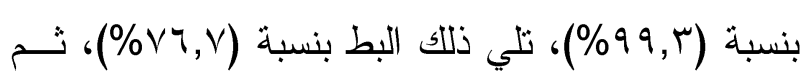

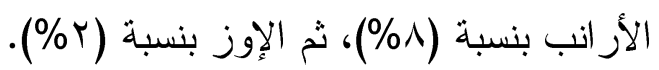

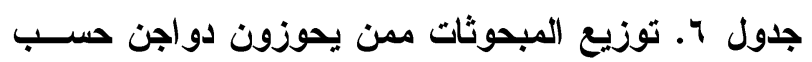

\begin{tabular}{|c|c|c|}
\hline$\%$ & التكرار ن= = 10 & النوع \\
\hline $99, r$ & $1 \leqslant 9$ & دجاج \\
\hline$V \Psi, V$ & 110 & بط \\
\hline$\Lambda$ & IY & أر أنب \\
\hline$r$ & $r$ & أوز \\
\hline
\end{tabular}

هذا وقد أظهرت الدراسة أن القيم الرقمية المعبرة عـن

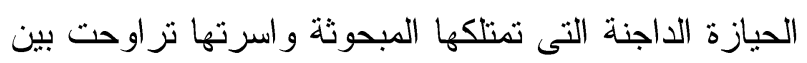

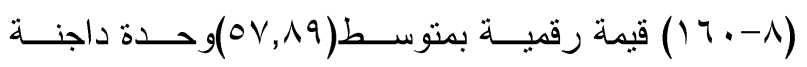

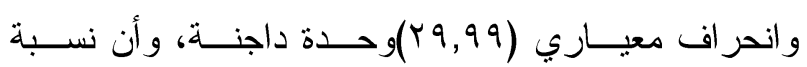
الاختلاف قد بلغت (1, وان (0)

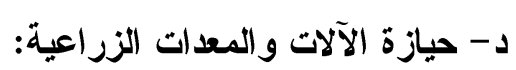

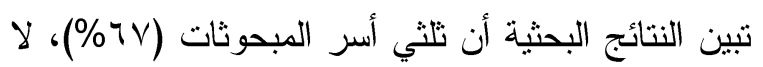

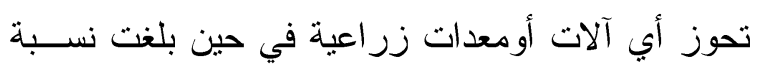

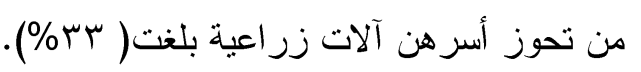

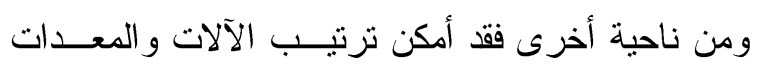

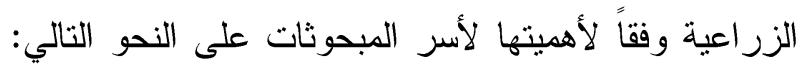

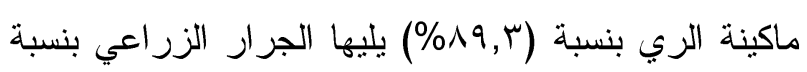

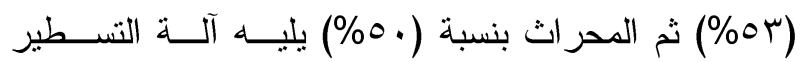

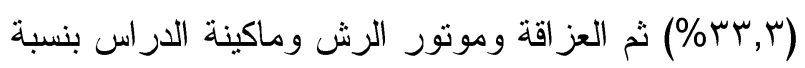

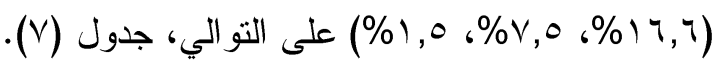

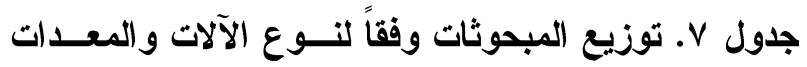
الزر اعية التي تحوزها الأسرة

\begin{tabular}{|c|c|c|}
\hline$\%$ & تكرار ن= צ 7 & نوع الآلات الزراعية \\
\hline$\wedge 9, r$ & 09 & ماكينة الري ل \\
\hline or & ro & جرار \\
\hline 0. & r & محر اث \\
\hline r & TY & آلة تسطير \\
\hline 17,7 & 11 & عز اقة \\
\hline$V, 0$ & 0 & موتور رش \\
\hline 1,0 & 1 & ماكينة در اس \\
\hline
\end{tabular}

أما فيما يتعلق بنوعية الحيو انات التي تحوزهــا بعضض

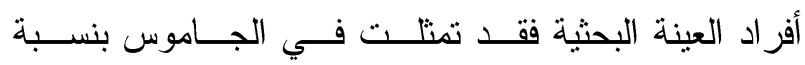

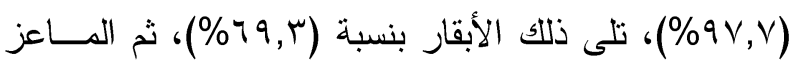

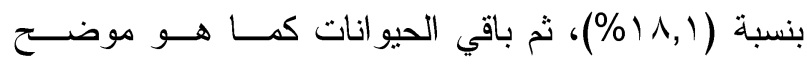

بالجدول (0).

جدول ه. توزيع المبحوثات ممن يحوزون حيوانات حسب النوعية

\begin{tabular}{|c|c|c|}
\hline$\%$ & التكرار ن = & النوع \\
\hline $9 \mathrm{~V}, \mathrm{~V}$ & 17 & جاموس \\
\hline 79,4 & 7) & أبقار \\
\hline $1 \wedge, 1$ & 17 & ماعز \\
\hline 10,9 & $1 \varepsilon$ & أغنام \\
\hline 0,7 & 0 & حمار \\
\hline 1,1 & 1 & جمال \\
\hline
\end{tabular}

وفيما يتعلق بوجود حظيرة للماثية فقد اتضح أن جميع الرئ

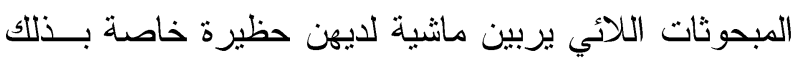
أما بالنسبة لمكان الحظيرة فقد أوضحت البيانات البحثية أن

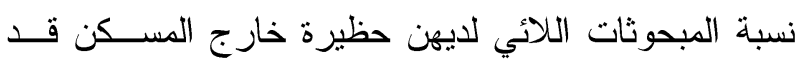

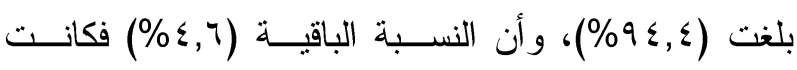

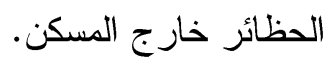

هذا وقد تبين من الدراسة كذلك أن القيم الرقمية المعبرة

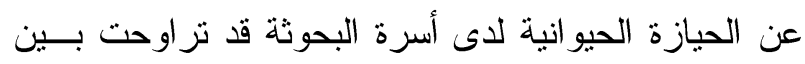

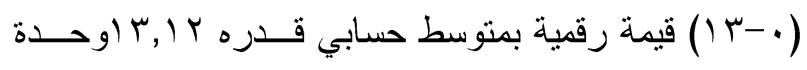

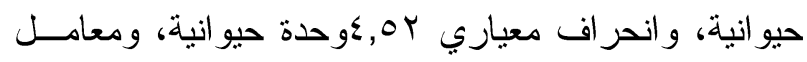
اختلاف يعادل ؟, ؟ب٪\%، وهذه النتيجة تعبر عن مدى التباين

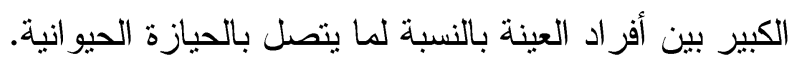

ج- الحيازة الاجنة: - الاجن

لا يمكن إغفال أن السعة الحيازة الداجنة تعــــ مؤشــراً

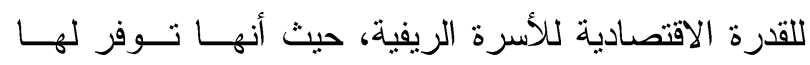

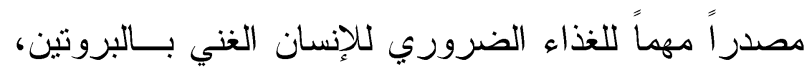

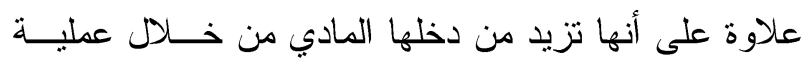

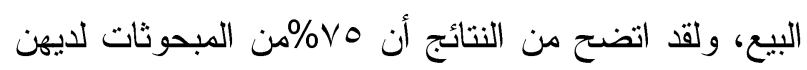
دو اجن وان النسبة الباقية (_, ؟r\%) لايحوزن ايه دو اجن. 
مجلة الإسكندرية للتبادل العلمى - (مجلد Vr العددץ) يوليو - سبتمبر 17 .

جدول 9 ـ توزيع المبحوثات وفقاً للأجهزة التــي تمتلكهــا

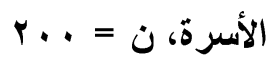

\begin{tabular}{|c|c|c|}
\hline$\%$ & التكرار & نوع الأجهزة \\
\hline 91,0 & $19 \mathrm{~V}$ & ثلاجة \\
\hline$\Lambda \leqslant, 0$ & 179 & تليفزيون عادي \\
\hline vo & 10. & غسالة عادية \\
\hline vo & 10. & بوتاجاز بفرن \\
\hline$\varepsilon 9$ & 91 & مسجل \\
\hline$r r, 0$ & $7 V$ & سخان مياه كهرباء \\
\hline rq & 01 & بوتاجاز مسطح \\
\hline$r V, 0$ & 00 & غسالة أوتوماتلك \\
\hline rV & $0 \leqslant$ & سخان مياه غاز \\
\hline 19,0 & rq & تلفيزيونِ بلازما \\
\hline 10,0 & M & تليفون أرضي \\
\hline
\end{tabular}

و - حيازة وسيلة مواصلات:

تشير النتائج البحثية الى أن غالبية المبحوثات لا تحوز

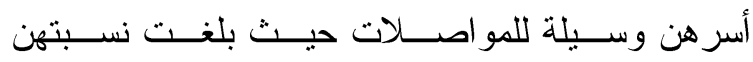
(\%VY,O) ( أما نسبة من يحوزون وسيلة مو اصدلات فقد

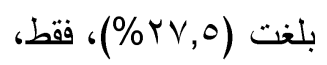
وبتوزيع المبحوثات وفقاً لنوعية وســيلة المواصــلات

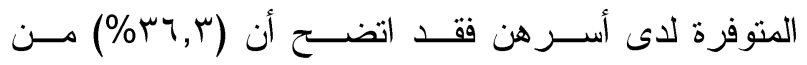

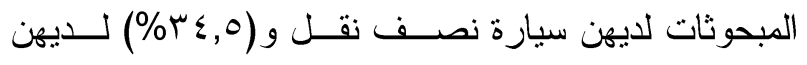
سيارة خاصة بينما بلغت نسبة من لديهن در اجــة بخاريــة

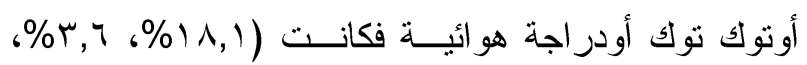

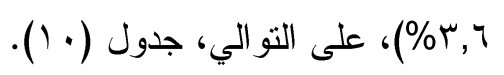

هذا وقد تبين من الدراسة كذلك أن القيم الرقمية المعبرة عن امتلاك وحيازة المبحوثات وأسرهن لوسائل المو اصلات فقد نز اوحت القيم الرقمية المعبرة عن ذلك بين ( . -ب) قيمة رقمية بمتوسط حسابي قدره ب, 1 ادرجة، و انحر اف معياري

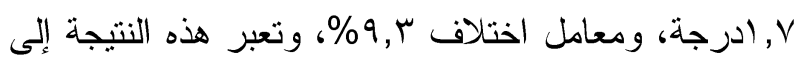
حد ما عن تقارب بين أفر اد العينة و انخفاض نسبة التبــاين

بينهم بالنسبة لباقي البنود السابقة.
هذا وقد تبين من الدر اسة كـذللك أن القـيم الرقميــة المعبرة عن الحيازة الخاصة بالمعدات و الآلات الزر اعية المملوكة للمبحوثة وأسرتها قد تر اوحت بين ( • -7) قيمة

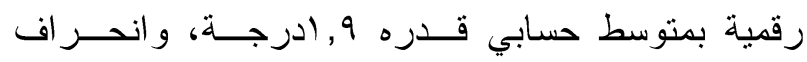

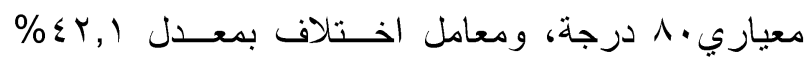
وهذه النتيجة تعبر عن إرتفاع التباين بين أفر اد العينة. هـ- اقتناء الأجهزة المنزلية: أوضحت النتائج البحثية أن القيم الرقمية المعبـرة عـنـ اقتتاء المبحوثات للأجهزة المنزلية قد تزاوحت بين (س- م ()

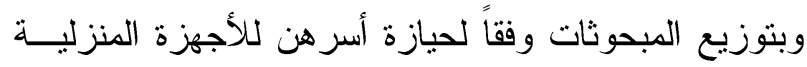

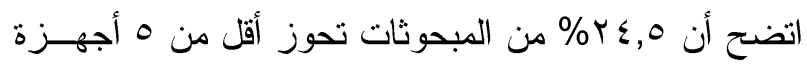

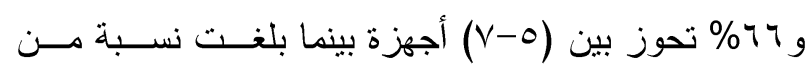
تحوز (1 فأكثر) 0,0\% وذلك مــن مجمــوع المبحوثــات،

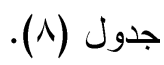

جدول ^. توزيع المبحوثات وفقاً لعدد الأجهزة التي تمتلكها

\begin{tabular}{|c|c|c|}
\hline$\%$ & العدد & عدد الأجهزة \\
\hline$r \leqslant, 0$ & $\varepsilon 9$ & أقل من 0 \\
\hline 79 & ITr & $V-0$ \\
\hline 9,0 & 19 & ᄉ فأكثر \\
\hline $1 \ldots$ & r... & المجمو ع \\
\hline
\end{tabular}

أما فيما يتعلق بنوعية الأجهزة التي تحوزها المبحوثات

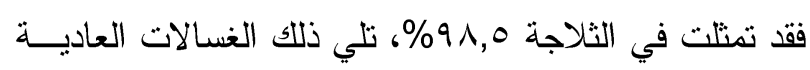

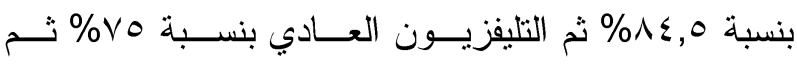

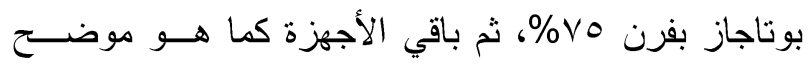

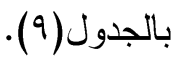
هذا وقد تبين من الدراسة كذلك أن القيم الرقمية المعبرة

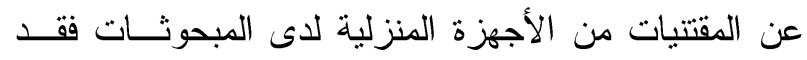
تز اوحت بين (Y-YM) قيمة رقمية، بمتوسط حسابي قـدره

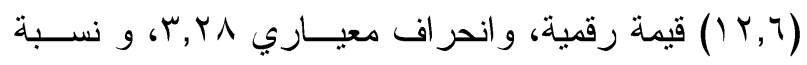

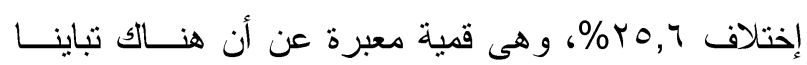
كبير البين المبحوثات. 
الأشخاص معرفه وخبره أوسع بالحيــاة وبدرجــة تفــوق

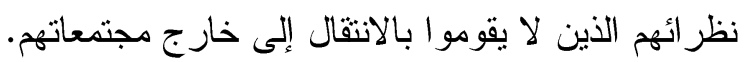
ولقد أظهرت النتائج الواردة بجــدول(1) (1) أن غالبيـــة

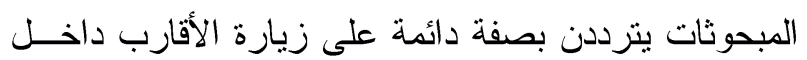

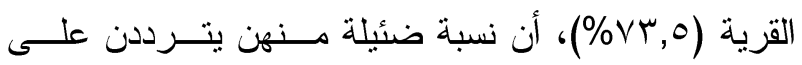

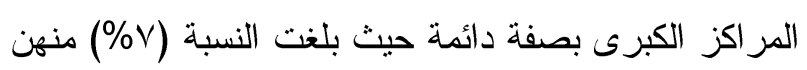

ب-التعرض لوسائل الإعلام: تعتبر كل من الإذاعة و التليفزيون و الصحف مــن أهـــ طرق الاتصال الفعالة حيث فيها الكلمة المسموعة و المرئية و المكتوبة التي تسهم في تحسين نظرة وفكرة الجمهور نحو

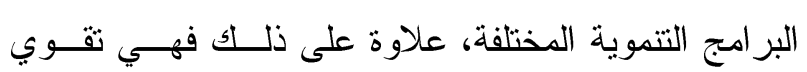
وتدعم طرق الاتصال الشخصي، كما انها تساعد في تبنـى الأفكار المتعلقة بالبيئة السكانية الريفية بصفة خاصة الصاص. ولقد أوضحت النتائج البحثية أن نسبة المبحوثات اللائي تستمعن إلى الراديو دائماً ؟r\% و أحياناً

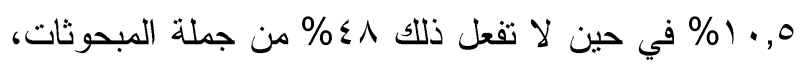

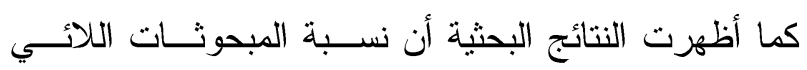

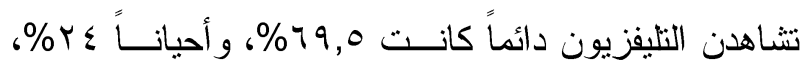

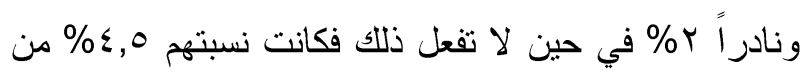

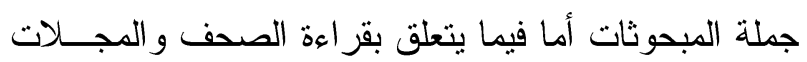

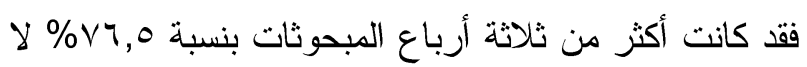

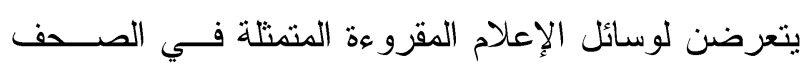

$$
\text { و المجلات، جدول( (1) ). }
$$

جدول 11 اـ توزيع المبحوثات وفقاً لمدى ترددهن على المناطق الحضرية

\begin{tabular}{|c|c|c|c|c|c|c|c|c|c|c|}
\hline \multicolumn{2}{|c|}{ المجموع } & \multicolumn{2}{|c|}{ أبلدا } & \multicolumn{2}{|c|}{ نادرا } & \multicolumn{2}{|c|}{ أحبانا } & \multicolumn{2}{|c|}{ دائما } & \multirow{2}{*}{ ملائ الثزدد على المناطق خارج } \\
\hline$\%$ & العدد & $\%$ & العدد & $\%$ & العدد & $\%$ & العدد & $\%$ & العدد & \\
\hline $1 \ldots$ & $r \ldots$ & rT & $\leqslant 7$ & ro & 0. & \&1,0 & N & $1 \cdot, 0$ & YI & التزدد على القرى المجاورة \\
\hline $1 \ldots$ & r... & 1 & $r$ & $r, 0$ & 0 & Tr & $\varepsilon\rceil$ & $V T, 0$ & $1 \leqslant V$ & زيارة الأهل و الأقارب بالقرية \\
\hline $1 \ldots$ & Y.. & $1 Y, 0$ & Yo & Y & or & $\varepsilon \varepsilon$ & $\wedge \Lambda$ & $1 V, 0$ & ro & زيارة الأهل و الأفارب خار ج القرية \\
\hline $1 \ldots$ & r.. & 10,0 & M & $r \wedge, 0$ & VV & Mr,o & 70 & $1 \pi, 0$ & tr & التزدد على مراكز القرية \\
\hline $1 \ldots$ & r.. & rY & $\varepsilon \varepsilon$ & $\leqslant 0$ & 9. & Yo,0 & 01 & $\mathrm{~V}, \mathrm{O}$ & 10 & التزدد على المر اكز القريية من القرية \\
\hline $1 \ldots$ & Y... & 01 & $1 . r$ & 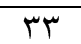 & 79 & $1 Y, 0$ & ro & r,o & V & التز دد على المر اكز الكبرى \\
\hline
\end{tabular}

جدول • ا ـ توزيع المبحوثات وفقاً لنوع وسيلة المواصلات

\begin{tabular}{|c|c|c|}
\hline$\%$ & تكرار ن= 00 & نوع وسيلة المو اصلات \\
\hline ry,r & $r$. & سيارة نصف نقل \\
\hline$r \leqslant, 0$ & 19 & يارة خاصة \\
\hline $1 \wedge, 1$ & 1. & در اجة بخارية \\
\hline$r, \tau$ & $r$ & توك توك \\
\hline$r, \tau$ & $r$ & در اجة \\
\hline
\end{tabular}

ثالثاً: الخصائص الاتصالية: 1- الانفتاح الحضاري:

يتيح الانفتاح الحضاري فرصة التعرف علــى أنمــاط

حياتية جديدة لمجتمعات أخري ويساعد على اقتباس وتبنـي

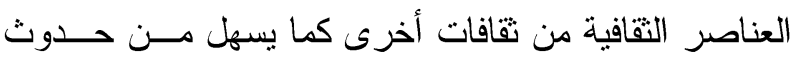
عمليات التبادل التكنولوجي و المعرفي ويؤدي إلـى تنــــين اتجاهات إيجابيه مشجعه ومسانده لعملية التنميـة، ( نبيـلـل

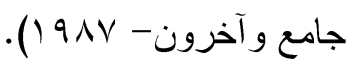
هذا ولقد تمنل هذا الانفتاح بتصنيف المبحوثات وفقاً للقيم الرقمية الدالة على درجة انفتاحهن التقافي إلى ثلاث فئـات

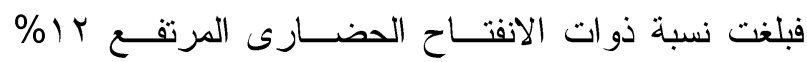

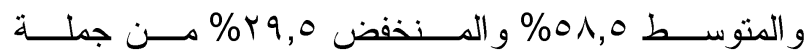
المبحوثات،هذا وقد تم قياس الإنفتاح الحضارى عن طريق

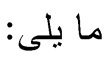
أ- التردد على المناطق خارج القرية: مما لا شك فيه أن الانتقال من القرية إلــى مجتمعــات

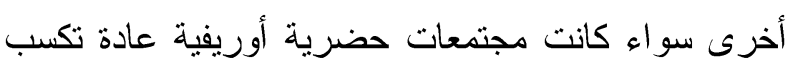


جدول r ا ـ توزيع المبحوثات وفقاً لمدى تعرضهن لوسائل الإعلام المختلفة

\begin{tabular}{|c|c|c|c|c|c|c|c|c|c|c|}
\hline \multicolumn{2}{|c|}{ المحمو ع } & \multicolumn{2}{|c|}{ أبدا } & \multicolumn{2}{|c|}{ نادرا } & \multicolumn{2}{|c|}{ أحياتًا } & \multicolumn{2}{|c|}{ دائما } & مدى التردد على المناطق \\
\hline$\%$ & اللعدد & $\%$ & الثعد & $\%$ & اللعدد العدا & $\%$ & 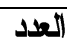 & $\%$ & الإلد & خارج القرية \\
\hline$\ldots$ & r... & $\mathrm{V} 4,0$ & 104 & $1 \cdot, 0$ & YI & 7,0 & 14 & 7,0 & $1 \pi$ & قر اءة الصحف و المجلات \\
\hline $1 \ldots$ & r... & $\varepsilon, 0$ & 9 & $\bar{Y}$ & $\varepsilon$ & $r \varepsilon$ & $\varepsilon \Lambda$ & 79,0 & $1+49$ & مشاهدة التليفزيون \\
\hline 1, & r.. & $\varepsilon \lambda$ & 97 & 1,0 & $r_{1}$ & $1 \mathrm{~V}, 0$ & ro & $T \xi$ & $\sum \lambda$ & سماع الر اليو \\
\hline
\end{tabular}

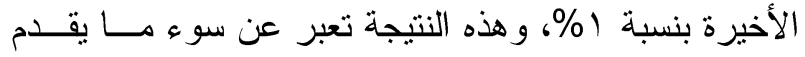

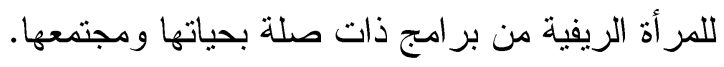
هذا ولقد تبين من الدراسة أن القيم الرقمية المعبرة عن لهان

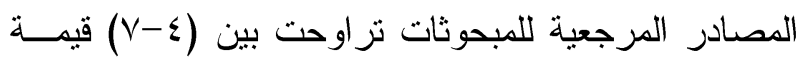

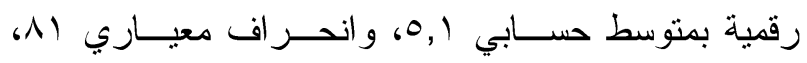

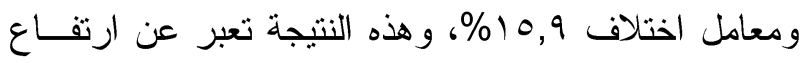

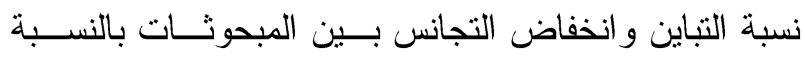

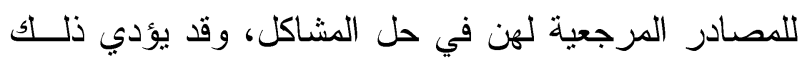
إلى نتيجة إيجابية و أفكار متعددة في حل المشاكل.

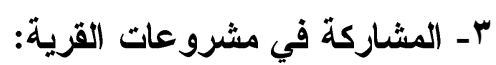

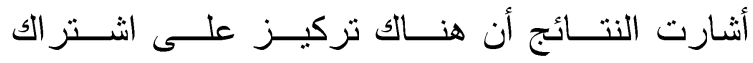

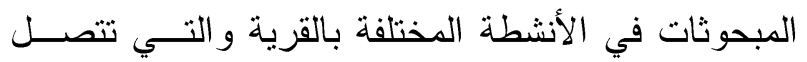

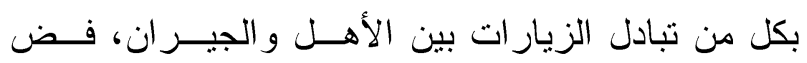
المنازعات بين سيدات القرية، نظافة القرية من النفايات

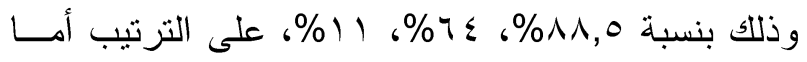

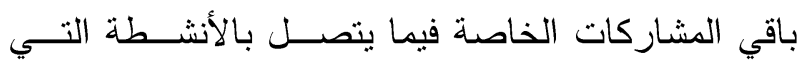

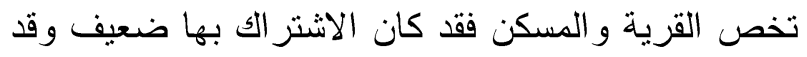

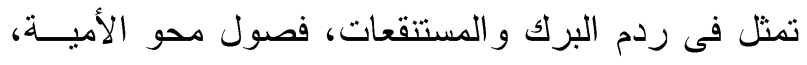

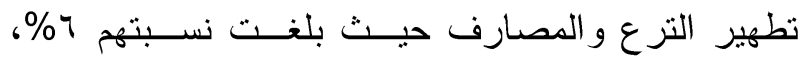

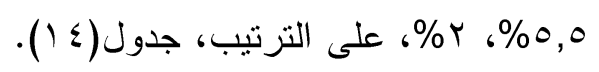

هذا وقد تبين من الدراسة أن القيم الرقمية المعبرة عـن الرئ

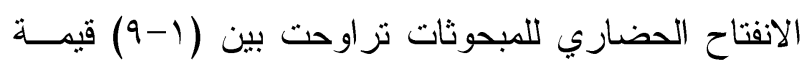

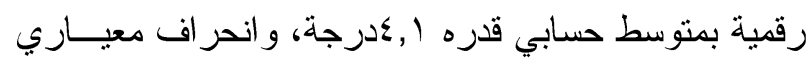

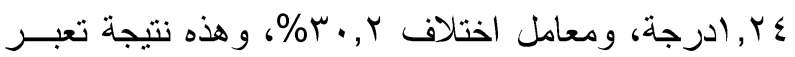

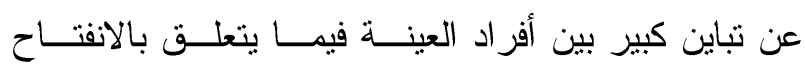
الحضاري لهن. r- المصادر المرجعية في حل المشاكل الأسرية: مما لا شك فيه أن تعرض المبحوثة لعـدد أكبـر مـن فئن

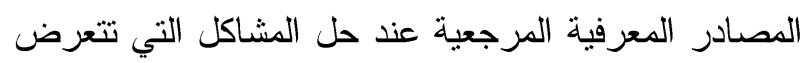

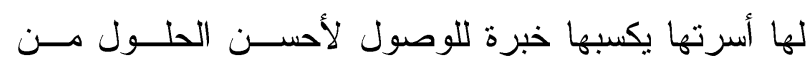
نظيرتها التي تعتمد على نفسها أو أحد من أفر اد أسرتها فقط لاحس

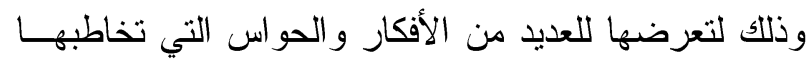
من تلاك المصادر.

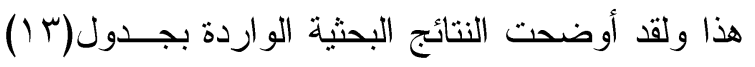

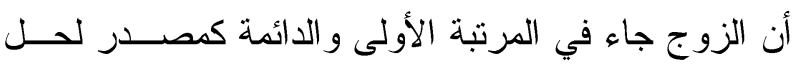

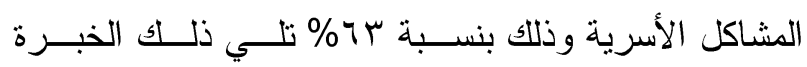

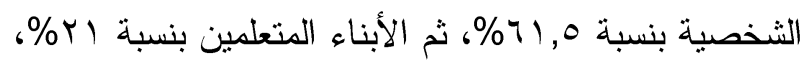

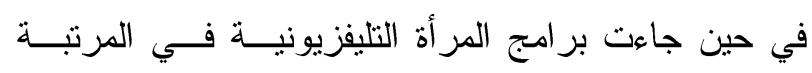

جدول با 1 ـ توزيع المبحوثات وفقاً لمصادرهن المرجعية لحل المشاكل الأسرية

\begin{tabular}{|c|c|c|c|c|c|c|c|c|c|c|}
\hline \multicolumn{2}{|c|}{ 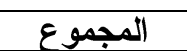 } & \multicolumn{2}{|c|}{ آبدا } & \multicolumn{2}{|c|}{ نادرا } & \multicolumn{2}{|c|}{ أحيانا } & \multicolumn{2}{|c|}{ دائما } & \multirow{2}{*}{ المصادر } \\
\hline$\%$ & العلدد & $\%$ & العدد & $\%$ & العلد العدا & $\%$ & 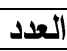 & $\%$ & العدد & \\
\hline $1 \ldots$ & Y.. & 14 & r4 & 7,0 & $\pi$ & $I V, 0$ & ro & $\pi$ & $1 \times 4$ & 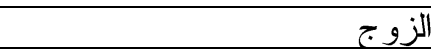 \\
\hline $1 \ldots$ & r... & $r$ & $\varepsilon$ & $\Lambda$ & 17 & $r \Lambda, 0$ & or & 71,0 & TKr & الخبرة الثخصية للزو ج او الزوجة \\
\hline $1 \ldots$ & Y.. & $\sum 1$ & Ar & r) & $\varepsilon Y$ & IV & $r \varepsilon$ & TI & $\varepsilon r$ & الآبناء المتعلمبن \\
\hline $1 \ldots$ & r... & $\varepsilon r$ & 14 & Yr,O & $\leqslant 0$ & Tr & $\sum 4$ & 11,0 & $\begin{array}{rr}\mu \\
T\end{array}$ & الآخوة والآخوات \\
\hline $1 \ldots$ & r... & $7 \cdot, 0$ & 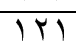 & $r \cdot, 0$ & « & $\Lambda$ & 17 & 11 & Yr & الجيران والأصدقاء \\
\hline $1 \ldots$ & Y.. & $\Lambda \varepsilon$ & $17 \mathrm{~V}$ & $\Lambda, 0$ & IV & r & $\varepsilon$ & 1,0 & $r$ & الصحف و المجلات \\
\hline $1 \ldots$ & r... & $\Lambda \mathrm{N}, \mathrm{O}$ & $17 \mathrm{~V}$ & $1 ., 0$ & r) & 0,0 & 11 &., 0 & 1 & ير امج المر أة التلبفزيونية \\
\hline .. & r... & 19 & IVA & 9,0 & 19 & 1,0 & $r$ & -1 & - & الجمعيات الأهلية \\
\hline$\ldots$ & r... & $9 \leqslant$ & $1 \mathrm{i \Lambda}$ & 0,0 & 11 & $\cdot, 0$ & & - & - & الحكّ \\
\hline
\end{tabular}


جدول ؛ ا. توزيع المبحوثات وفقاً لمدى مشاركتهن في مشروعات القرية

\begin{tabular}{|c|c|c|c|c|c|c|c|c|c|c|c|c|}
\hline \multicolumn{2}{|c|}{ تبادل الزيارات } & \multicolumn{2}{|c|}{ المناز عات } & \multicolumn{2}{|c|}{ فصول محو الأمية } & \multicolumn{2}{|c|}{ نظافة الثقرية } & \multicolumn{2}{|c|}{ و المستنقعات } & \multicolumn{2}{|c|}{ وتطهير الثرع } & \multirow{2}{*}{ العردروعات } \\
\hline$\Lambda \wedge, 0$ & IVV & $7 \varepsilon$ & IYA & 0,0 & 11 & 11 & YY & 7 & IY & $r$ & $\varepsilon$ & \\
\hline 11, & Yr & ry & $V Y$ & $9 \leqslant, 0$ & 119 & 19 & $1 \vee \wedge$ & $9 \leqslant$ & $1 \wedge \Lambda$ & 91 & 197 & $y$ \\
\hline $1 \ldots$ & $r \ldots$ & $1 \ldots$ & $r \ldots$ & $1 \ldots$ & r.. & $1 \ldots$ & r.. & $1 \ldots$ & $r \ldots$ & $1 \ldots$ & r.. & المجمو \\
\hline
\end{tabular}

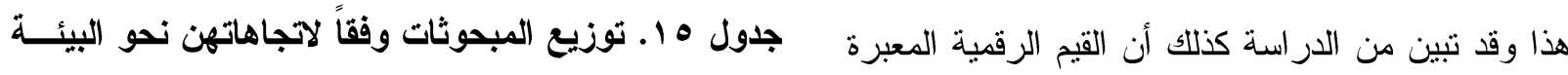

السكنية السليمة

\begin{tabular}{|c|c|c|}
\hline$\%$ & العدد & فئات الاتجاهات \\
\hline $\mathrm{V}$ & $1 \leq$ & سلبى (I'Y-Yo) \\
\hline$\varepsilon \mu$ & 14 & محايد (צr-r.r) \\
\hline 0. & $1 \ldots$ & 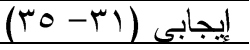 \\
\hline 1.. & r.. & المجمو ع \\
\hline
\end{tabular}

يلاحظ من بيانات الجدول الســابق أن قرابــة نصــف عابـ

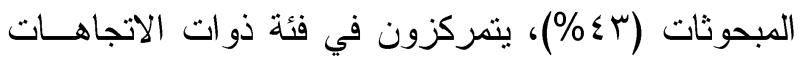

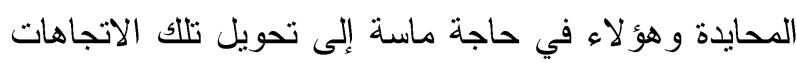

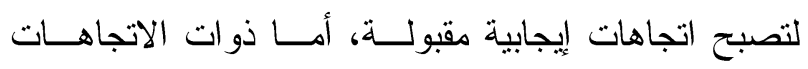

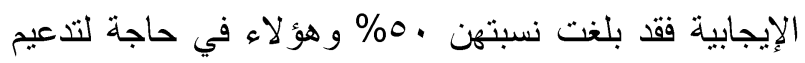

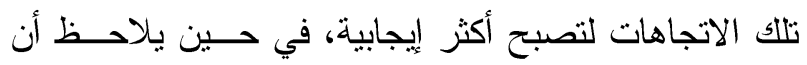

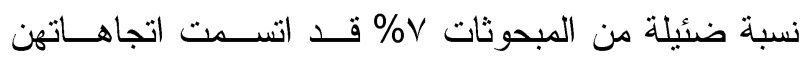
بالسلبية. وفيما يتصل بعبارات قياس اتجاهات المبحوثــات نحسـو

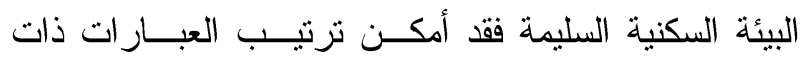

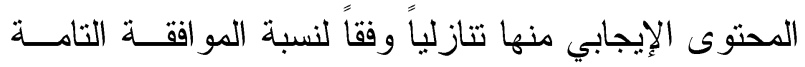

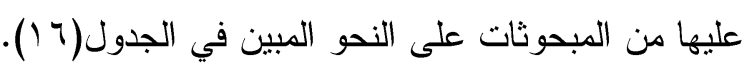

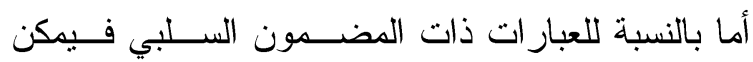

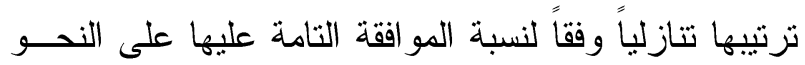

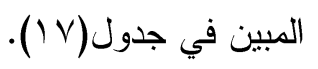

جدول 14 .الترتيب التنازلي لعبارات قياس اتجاهات المبحوثات نحو البيئة السكنية السليمة ذات المحتوى الإيجابي لنسـبة مو اققتهن التامة عليها

\begin{tabular}{|c|c|c|}
\hline$\%$ & العدد & العبــــارة \\
\hline $9 r, 0$ & 110 & ا. استخدام المو اد المطهرة في تتظف دورة المياه \\
\hline 94 & $1 \wedge \varepsilon$ & r. دخول المياه النقية بالمسكن بياعد على علم التعرض للأمر اض التى تصبب الإنسان \\
\hline 9$)$ & $1 \wedge Y$ & 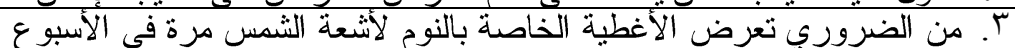 \\
\hline 91 & $1 \wedge Y$ & ع. استخدام المو اد المطهرة في تتظيف أرضية المسكن \\
\hline 9. & $1 \wedge$. & ○. نظافة المسكن تؤثر على صحة الأفر اد " \\
\hline$\wedge 9$ & $i \vee \Lambda$ & 7. المفروض أن ينظف المسكن كل يوم \\
\hline$\wedge \wedge$ & $1 V 7$ & V. وجود نو افذ كبيرة مهمة لتهوية المسكن \\
\hline AV & IV乏 & ^. أُفضل مكان لحظيرة المو اشثى خار ج المنزل \\
\hline
\end{tabular}

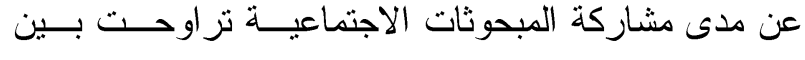

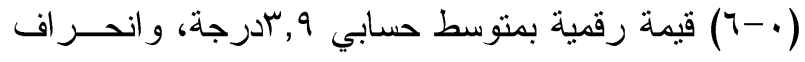

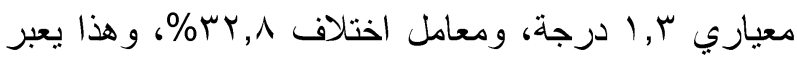
عن تباين كبير بين أفراد العينة بالنسبة لما يتصل بالمشاركة ومعاري الاجتماعية، وتعبر هذه النتيجة عن نقص الوعي لدى الكثير من المبحوثات عن مدى أهمية دورهــن فــي المســاهمة و المشاركة في الحياة الإجتماعية على المستويين الأســري ع - اتجاهات المبحوثات نحو البيئة السكنية السليمة: بدر اسة اتجاهات المبحوثات نحو البيئة السكنية الســليمة

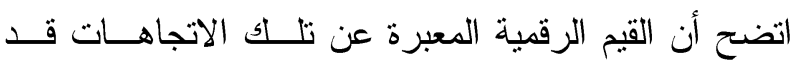

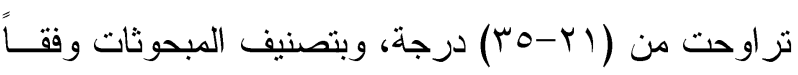
للدرجة المعبرة عن إتجاهاتهن نحو البيئة السكنية السـليمة إلى ثلاث فئات، تبين أن نسبة ذوات الاتجاهات الإيجابيــة

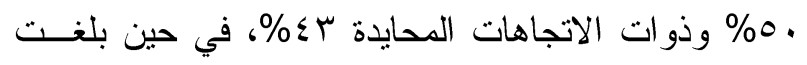
نسبة ذوات الاتجاهــات الســلبية V\% فقـ طـ مــن جملــة

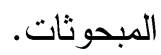




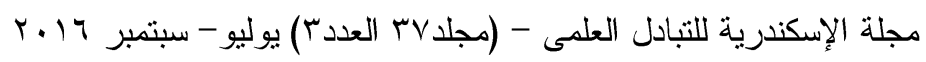

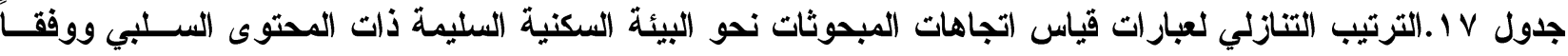

لنسبة مواقتتهن التامة عليها

\begin{tabular}{|c|c|c|}
\hline$\%$ & 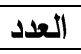 & 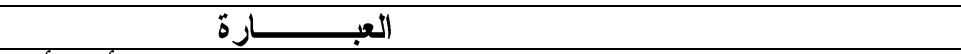 \\
\hline 94 & 114 & 1 - كلما كانت المساكن قريبة جدا من بعض كلما كان هناك شعور بالأمان أكثر \\
\hline$\wedge 9,0$ & $1 \vee 9$ & r - أفضل وسيلة للقضاء على الحشر ات المنزلية استخدام الـــد،د،ت \\
\hline$\wedge \wedge$ & $1 \vee 4$ & ب- أشعة الثمس أفضل وسيلة للتخلص من الرو ائح الكريهة و الآفات \\
\hline$\Lambda \varepsilon$ & 171 & ع - يفضل تربية الدو اجن داخل المسكن عن الشر اء من السوق \\
\hline 00 & 11. & 0- أفضل مكان لتربية الدو اجن بحوش المسكن \\
\hline$r \wedge$ & 07 & ؟- لمبات الكهرباء ذات الضوء الأحمر أفضل من ذات الضو ء الأبيض \\
\hline$r \leqslant, 0$ & $\varepsilon 9$ & V- أفضل وسيلة للتخلص من الحيو انات و الطيور النافقة إلقاؤها في التز ع و المصارف \\
\hline$r Y, 0$ & కo & 1- أفضل وسيلة للتخلص من الفضلات و القمامة إلقاؤها أمام المسكن \\
\hline 11,0 & tr & 9- تجريف التربة يحسن من خو اص الأرض الزر اعية \\
\hline 0,0 & 11 & • 1- أفضل حرق الخشب للتدفئة في فصل الشتاء \\
\hline
\end{tabular}

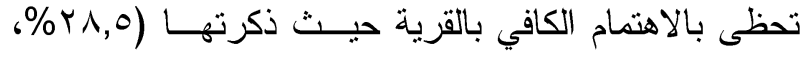

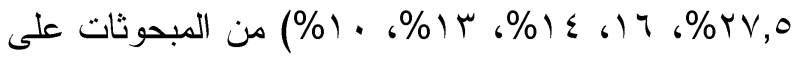

التزتيب.

هذا وقد تبين من الدراسة كذلك أن القيم الرقمية المعبرة عن البيئة العمرانية و التكنولوجية للقرية موضع الدراسة قد

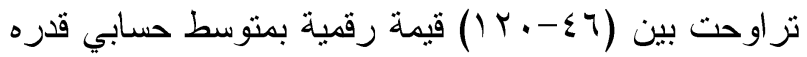

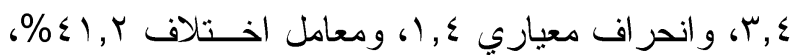

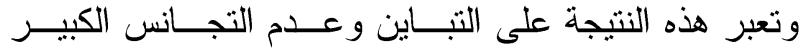
للتغير ات المعمارية و التكنولوجية بالقرية موضع الدراســة، وهذا قد يرجع إلى العشوائية في التجديد و التغيير بالقريــة

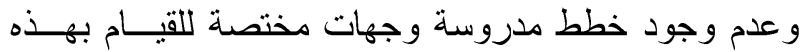

ثانيا: النتائج المتصلة بالتغيرات في الشكل العام للقرية:

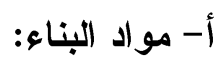

أظهرت النتائج البحثية أن (99\%) من مساكن القريـــة مشيدة بالطوب الأحمر، تللي ذلك كل من الطوب الأســـنتي لتهني و الحجر الجيري حتى بلغت نسبتهما على التو الي (1,0 (1\%،

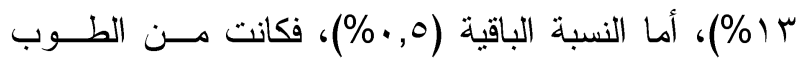
الفخاري.

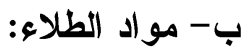
أظهرت النتائج البحثية أن مادة البلاستيك جاءت في مقدمة مو اد الطلاء المستخدمة في مساكن القرية حيــث
هذا وقد اوضحت الدراسة على أن القيم الرقمية المعبرة عن إتجاهات المبحوثات الإجابية و السلبية نحو البيئة السكنية

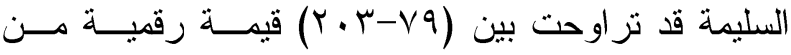

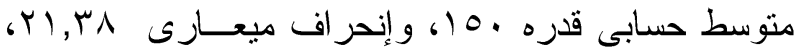
ومعامل إختلاف ب,؟ إ\% وهو ما يعبر عن الإرتفاع النسبى بين المبحوثات فيما يتعلق بإتجاهاهن نحو البيــة الســكنية السليمة. النتائج المتصلة بالخصائص العمر انية والتكنولوجية للقرية اولا:النتائج المتصلة بالتغيرات الحادثة بالقرية:

تعتبر البيئة العدر انية في القرية المصرية بيئـة محليــة حيث يعيش حوالي 07\% من تعداد السكان في جمهوريـة مصر العربية في الريف، ومع ذلك لا تلقى هذه البيئة القدر الكافي من الاهتمام حتى في الدر اسـات العلميــة المنظمـــة،

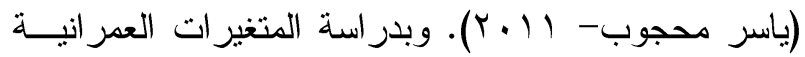
و التكنولوجية الحادثة بالقرية موضع الدر اسة فقد تبين مـن

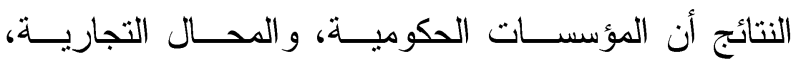
و الأسواق، الحضانات و المستشفيات على قــــة التغيـرات الحادثة في القرية حيث بلغت نسبة مــن ذكرتهـــا بنســبـ

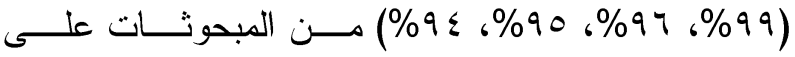
الترتيب، كما أوضحت النتائج البحثية أن مر اكز التـدريب، تعليم الكبار ، رصف الثوارع الرئيسية و الفرعيــة، إنشــــاء

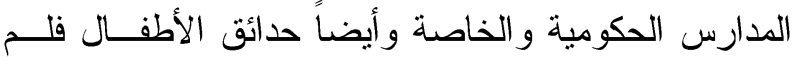


جدول1 اـ توزيع المبحوثات وفقاً لمعرفتهن بأنواع مسـواد البناء المستخدمة في القرية

\begin{tabular}{|c|c|c|c|c|}
\hline \multicolumn{2}{|c|}{ لا بعرف } & \multicolumn{2}{|c|}{ يعرف } & \\
\hline$\%$ & الإعدد & $\%$ & العدد & واع \\
\hline 11 & Yr & 19 & 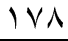 & أسمنت عادي \\
\hline 19,0 & 19 & $\Lambda \cdot, 0$ & 171 & أسمنت سريع \\
\hline rA & 04 & VY & $1 \leqslant \varepsilon$ & أسمنت أبيض \\
\hline$\varepsilon \wedge$ & 97 & Or & $1 \cdot \varepsilon$ & جبس \\
\hline 00,0 & 111 & $\varepsilon \leqslant, 0$ & 19 & مو اد عازلة للرطوبة \\
\hline $7 \Lambda$ & 4Tו1 & r & $7 \varepsilon$ & مصنيص \\
\hline
\end{tabular}

و - ألوان دهانات الحو ائط الخارجية:

أشارت النتائج الواردة بجدول (9 1) أن اللون الأخضر

الداكن هو أكثر الألوان شيوعاً في طلاء الحوائط الخارجية

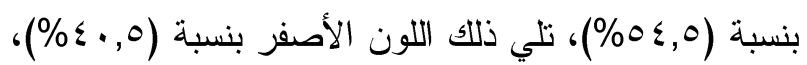
ثم البرتقالي بنسبة (rr\%)، في حين تعادل كل من اللونين

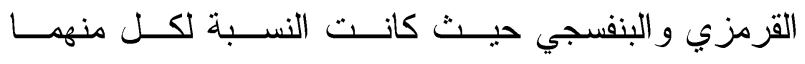

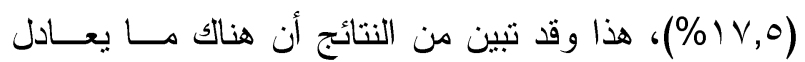

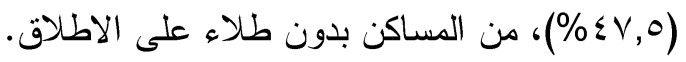

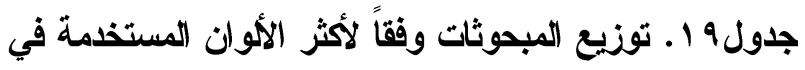

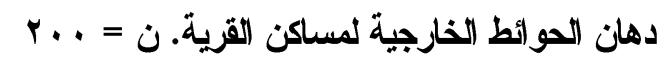

\begin{tabular}{|c|c|c|}
\hline$\%$ & تكر ار & الألــــــــــوان \\
\hline $0 \leqslant, 0$ & 1.9 & الأخضر الداكن \\
\hline$\varepsilon V, 0$ & 90 & بدون طلاء \\
\hline$\varepsilon, 0$ & N1 & الأصفر \\
\hline$r v$ & $V \varepsilon$ & البرتقالي \\
\hline rI & $\varepsilon r$ & الييج \\
\hline $1 V, 0$ & ro & القزمزي \\
\hline $1 V, 0$ & ro & البنفسجى \\
\hline 10 & $r$. & البنى \\
\hline $1 \leq$ & $r \Lambda$ & الأزَرق \\
\hline
\end{tabular}

ز - نوعية الثبابيك المستخدمة بمساكن القرية:

بسؤال المبحوثات عن أكثر أنــــواع الثـــبابيك انتشـــاراً

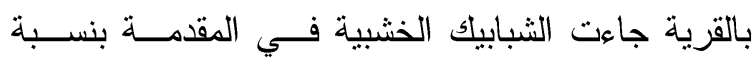

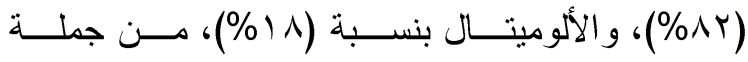

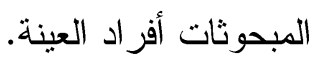

ذكرتها (, (r/\%) من المبحوثات، تلي ذلك كل من دهان

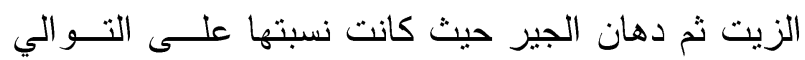

$$
\text { .(\%ro 6\%rr,o) }
$$
ج- أنواع الأرضيات: تبين من النتائج أن السير اميك جاء في مقدمــة أنــــواع

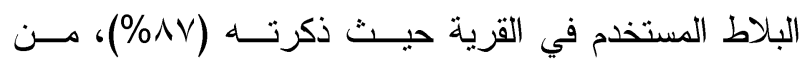
المبحوثات، تلي ذلك كل من الموز اييك بنسبة (7ه\%)، ثــ البلاط الأسمنتي بنسبة (ربr\%).

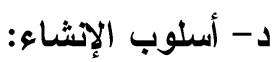

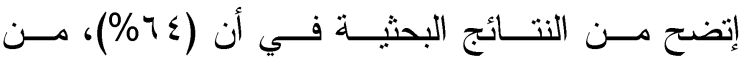

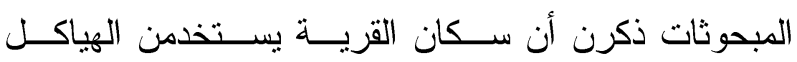
الخرسانية في بناء مساكنهن الجديدة بينما ذكــرت (Tr\%\%)، منهن أن الأسلوب الأكثز إنتشار الفي بناء المساكن الحديثـــة بالقزية هو الحوائط الحاملة. أما فيما يتعلق بنوعية الأساس المستخدم في الإنشاء فقد

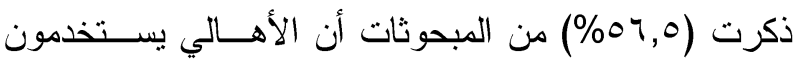

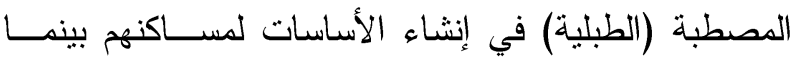

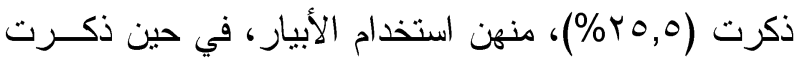

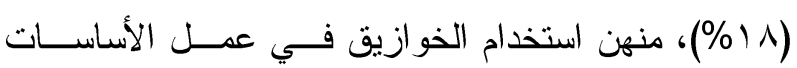
بالمساكن داخل القرية. هـ- أنواع مواد البناء: بسؤال المبحوثات عن مدى معرفتهن بمو اد البناء الأكثر

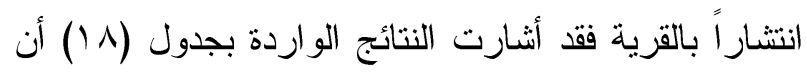
كل من الأسمنت العادي و السريع جاء في المقدمــة بنســبة

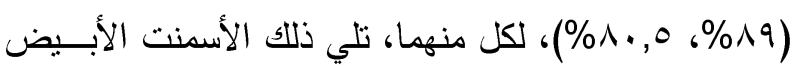
بنسبة (\%VY\%)، في الوقت الذب جاء المصيص في المرتبة الأخيرة بنسبة (rr\%). 
أما عن نوعية الأراضي التي تقام عليها المساكن بالقرية

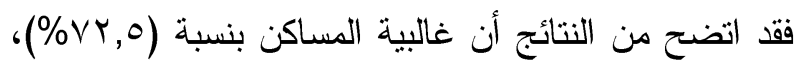
كانت جزء من أرض زر اعية وجزء أرض مباني، وأن ما

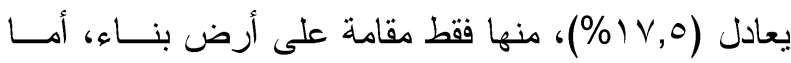

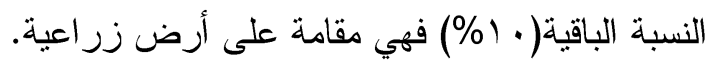

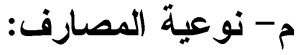

بالسؤ ال عن نوعية المصارف المنو اجدة بالقرية موضع

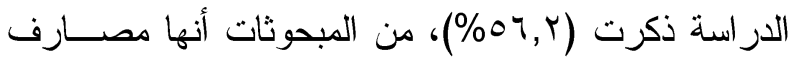
مكثوفة، الأمر الذي يجعل البيئة السكنية ملوثة بالحشرات

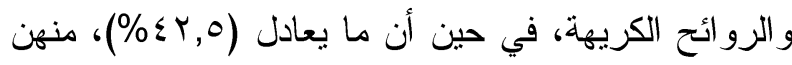

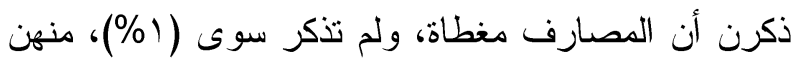
أنه لا توجد أية مصارف قريبة من المساكن.

\section{ي - نوعية مطلات المساكن بالقرية:}

بالسؤ ال عن نوعيـة المطــلات الخاصــة بالمســاكن المتو اجدة بالقرية ذكرت غالبيــة المبحوثـــات ( الارض الزرارعية، فـى حسين ذكـرت (بآ\%) مــنهن

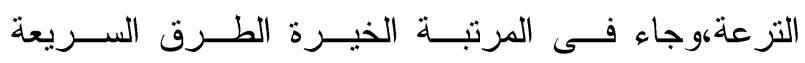

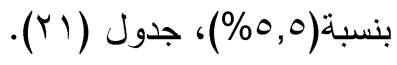

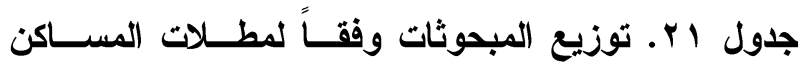

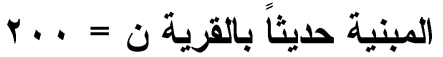

\begin{tabular}{|c|c|c|}
\hline$\%$ & تكرار & المطلات \\
\hline$V \varepsilon, 0$ & $1 \leq 9$ & أرض زر اعية \\
\hline$\pi$ & $1 K 4$ & 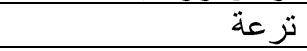 \\
\hline 71 & IKY & شو ار ع رئيسية مخططة \\
\hline 19 & $\mu_{\mu}$ & مصارف \\
\hline 0,0 & 11 & طرق سريعة \\
\hline
\end{tabular}

النتائج البحثية المتصلة بالتصميم الإخلي وحالة المســكن

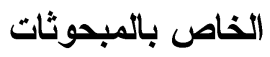

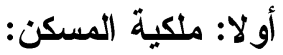

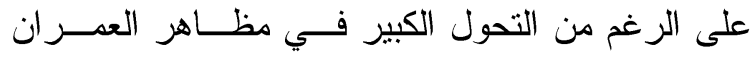
الريفي خلال العقود الأربعة الماضية ووجود مظاهر عديدة

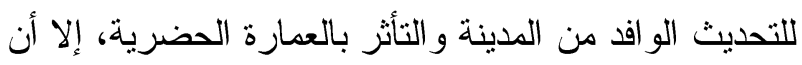

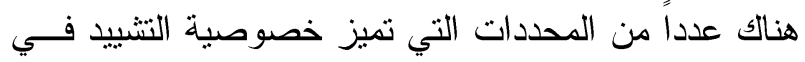

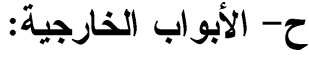
اتضح من النتائج البحثية أن أكثر من نصــف المبحوثـات

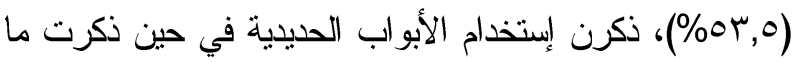

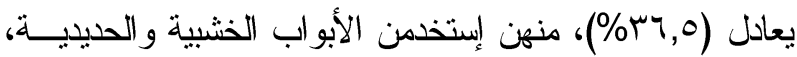

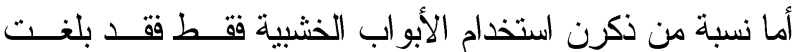
$.(\%) \cdot, 0)$ ط- عدد الطو ابق بمساكن القرية: دلت النتائج الواردة أن ما يقرب من نصــف مســاكن القرية موضع الدراسة تتكون من أربعة طوابق حيث ذكرتها

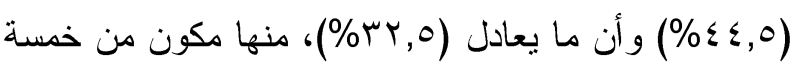
طو ابق، أما النسبة الباقية فقد ذكرت المبحوثات أنها عبـارة

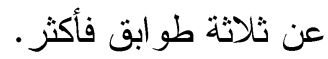
ك- المر افق الأساسية بالقرية:

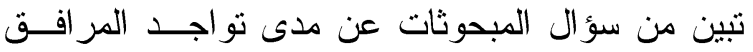
الأساسية بالقرية أن الغالبية العظمى منهن ذكرن تواجد البد كل

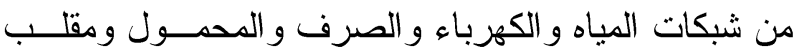

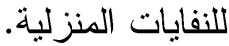

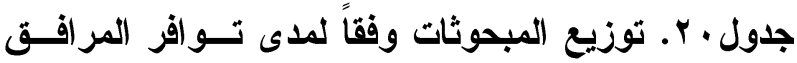

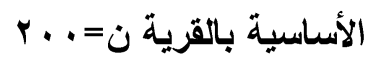

\begin{tabular}{|c|c|c|c|c|}
\hline \multicolumn{2}{|c|}{$\gamma$} & \multicolumn{2}{|c|}{ نعو } & \\
\hline$\%$ & إلعدد ال العد & $\%$ & العدد & الآســـــواع \\
\hline., 0 & 1 & 99,0 & 199 & شبكة كهرباء \\
\hline$\cdot, 0$ & 1 & 99,0 & 199 & محطة محمول \\
\hline 1 & r & 99 & 191 & شبكة مياه نقيه \\
\hline 1 & $r$ & 99 & 191 & شبكة صرف صح \\
\hline 11 & $r 4$ & $\lambda r$ & $17 \varepsilon$ & مقلب للنفايات \\
\hline
\end{tabular}

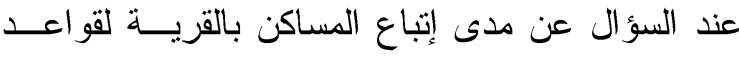
التنظيم و التخطيط تبين من النتائج أن الغالبية مـن مســاكن

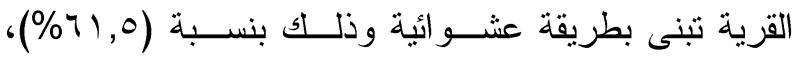

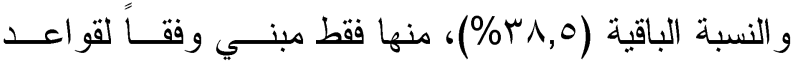
التنظيم بالقرية. 
جدول r r. توزيع المبحوثات وفقاً لنوعية المسكن

\begin{tabular}{|c|c|c|}
\hline$\%$ & العلد & النوعية \\
\hline$\Lambda \varepsilon, 0$ & 179 & مسكن مستقل \\
\hline$\lambda, 0$ & IV & وحدة سكنية \\
\hline v & $1 \varepsilon$ & دور بالعمارة \\
\hline $1 \ldots$ & r... & المجمو ع \\
\hline
\end{tabular}

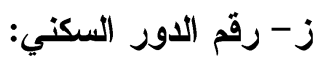

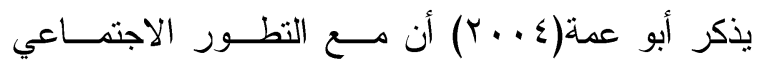

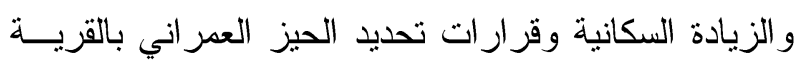

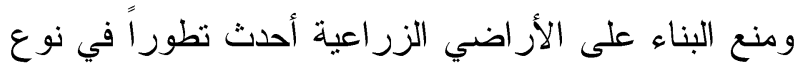

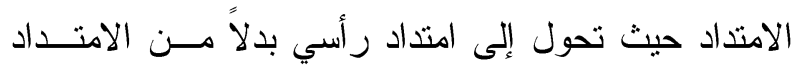

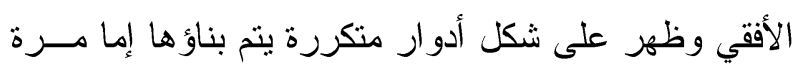

$$
\text { و واحدة أو على فنزات زمنية. }
$$

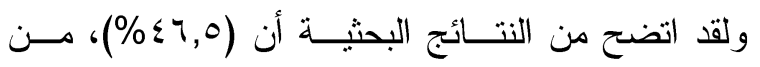

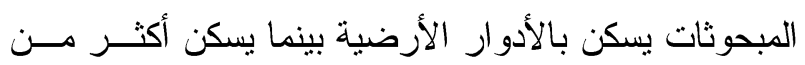

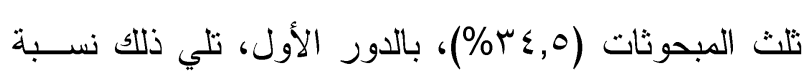
من يسكن بالدور الثاني فأكثر (9 (\%)، بالات الأور).

\section{ح- عدد سنوات الإقامة بالمسكن:}

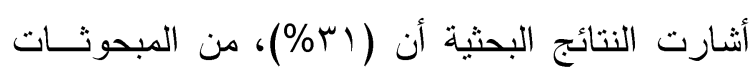

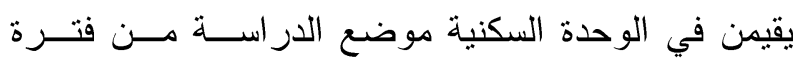

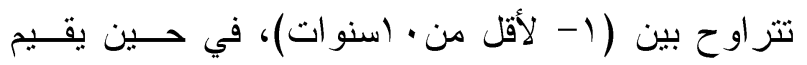

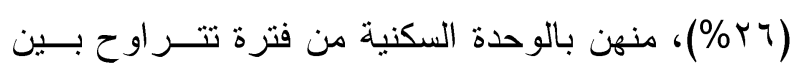

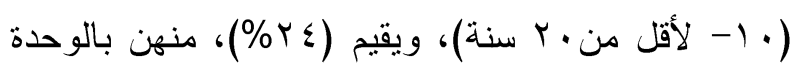

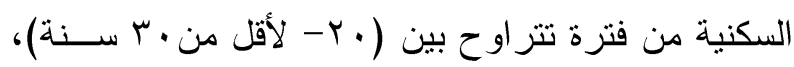

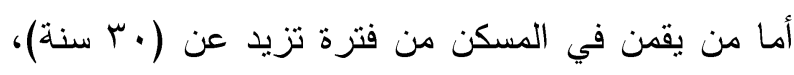
فقد بلغت نسبتهن (9 (1\%)، من جملة أفر اد العينة.

\section{ي- عدد الغرف بالمسكن:}

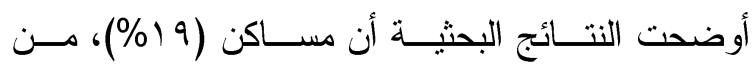

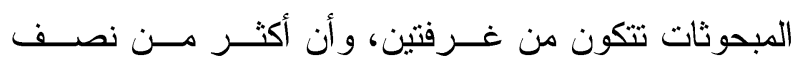

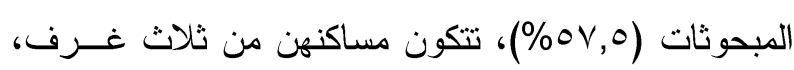

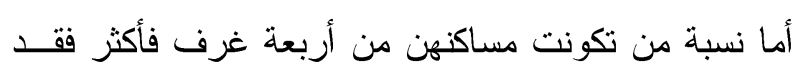

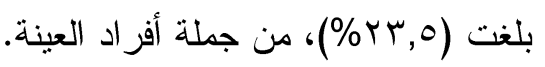

المناطق الريفية، ومن أهم هذه المحددات ملكيــة المســكن، المكنة

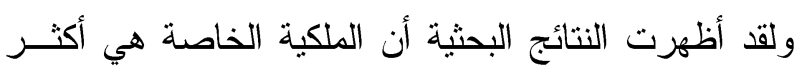

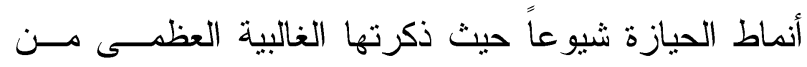

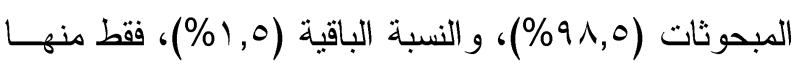

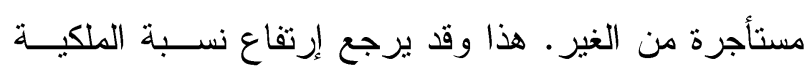

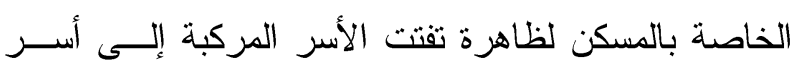
نووية.

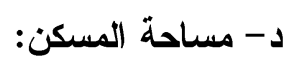

يتبين من النتائج البحثية أن نسبة المبحوثات اللاتــي

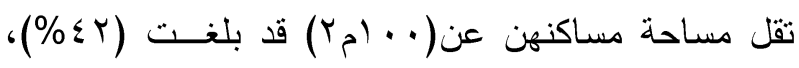

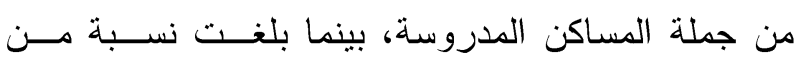

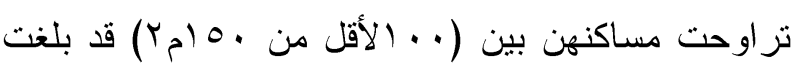

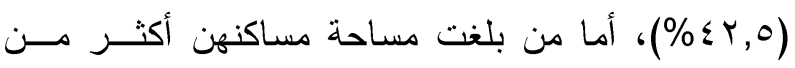

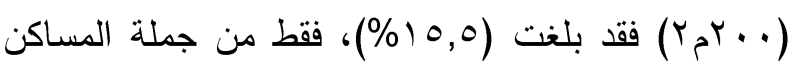

$$
\text { المدروسة. }
$$

\section{هـ- عدد سنوات إنثاء المسكن:}

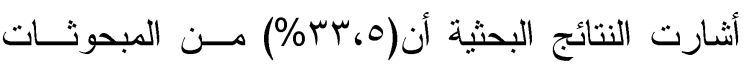

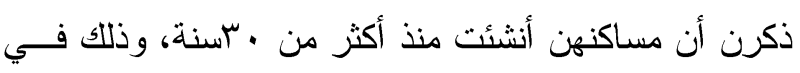

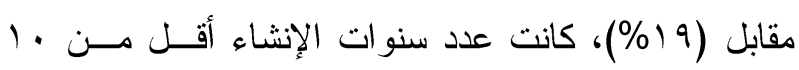

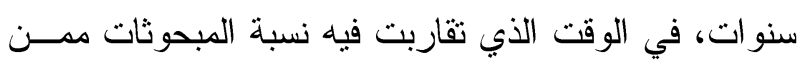

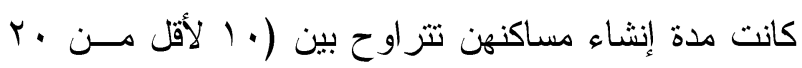

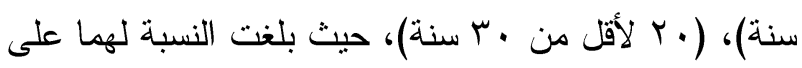

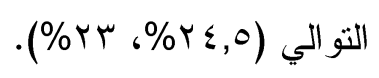

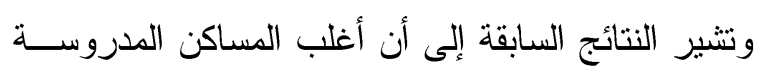

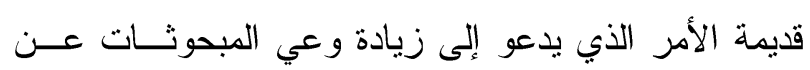
ضرورة التجديد و التحديث لمساكنهن. و - نوعية المسكن:

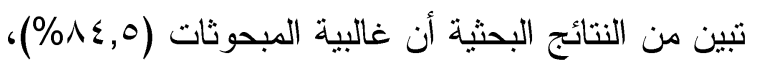

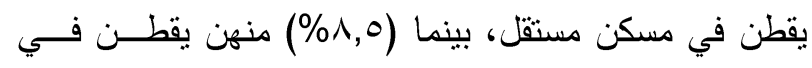

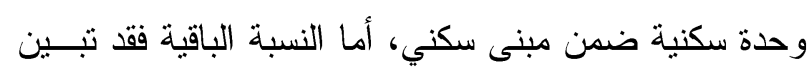
أنهن بمتلكن دور كامل بمبنى سكني. 
ن- درجة التزاحم الحجري بمساكنهن:

ينضح من النتائج البحثية أن (r؟\%\%)، من المبحوثــات

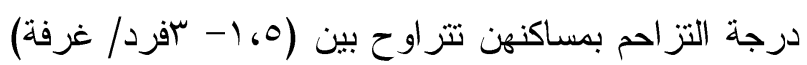

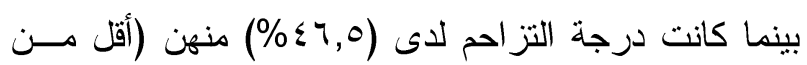

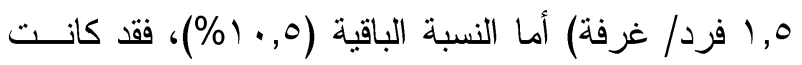
مزدحمة حيث بلغت درجة التز احم بها (ب فأكثر).

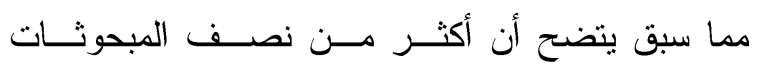

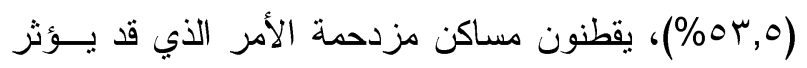

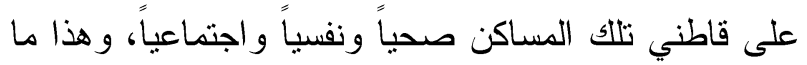

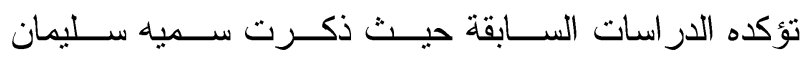

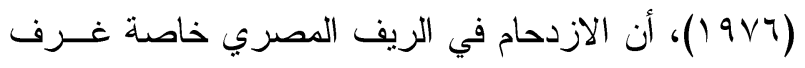

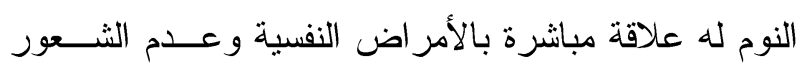

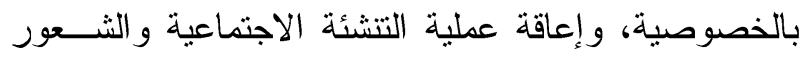

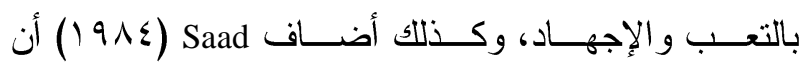

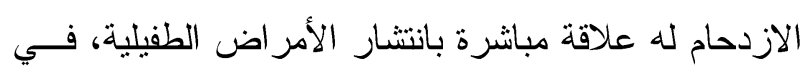

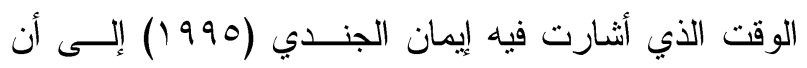

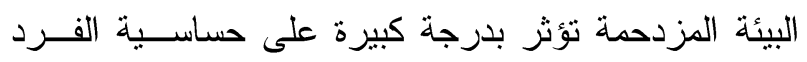
للمشكلات التي يو اجهها. س- نوعية دهان الحوائط: تبين من النتائج البحثية أن مادة دهان البلاستيك جـاءت

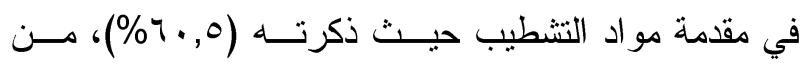

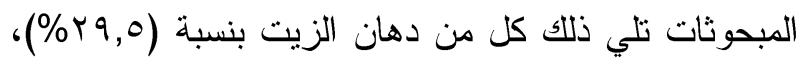

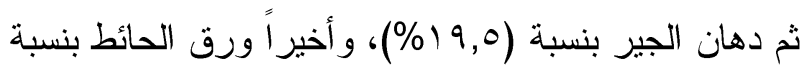

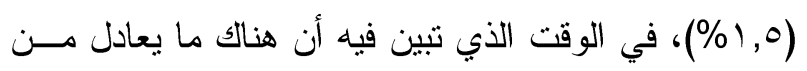

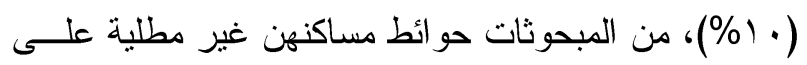

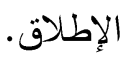
ع- مادة تثطيب النو (قذ:

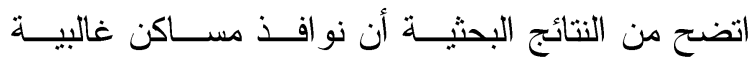

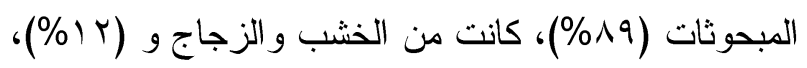

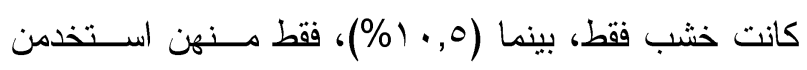

ك- مادة بناء المسكن:

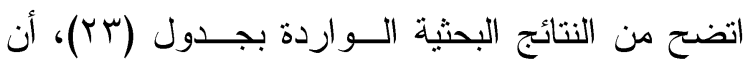

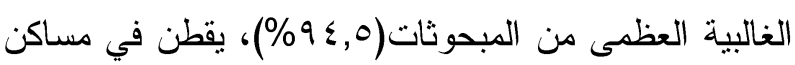

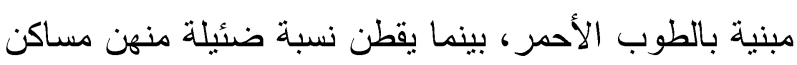

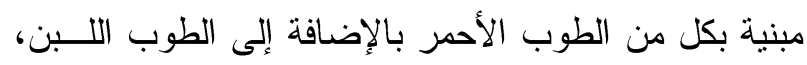

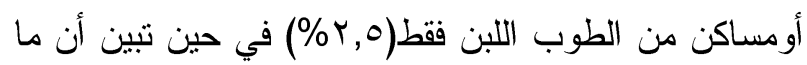

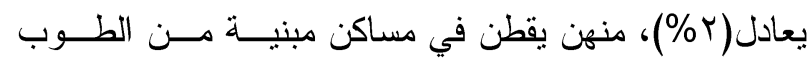
الأسمنتي. ل - ل مادة الأساس:

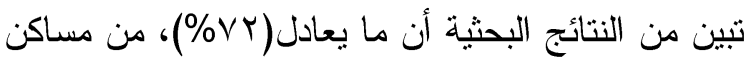

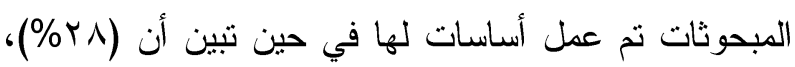
مبني بدون أساسات.

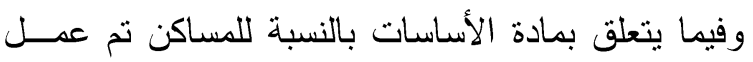

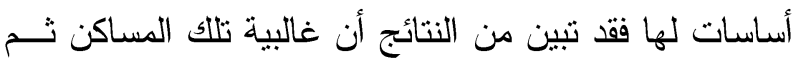

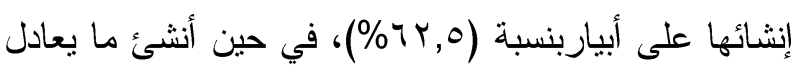

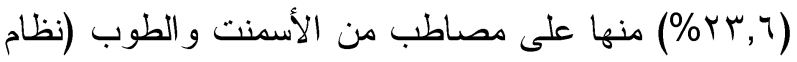

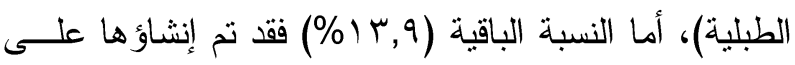
خوازيق أسمنتية. جدول ب r. توزيع المبحوثات وفقاً لمادة بناء المسكن

\begin{tabular}{|c|c|c|}
\hline$\%$ & العدد & لمــــــــادة \\
\hline $9 \xi, 0$ & 119 & لزوب أحمر \\
\hline$r, 0$ & 0 & طوب أحمر + لبن \\
\hline r & $\varepsilon$ & لطوب الأسمنتى \\
\hline 1 & Y & لطوب اللبن \\
\hline $1 \ldots$ & $r \ldots$ & 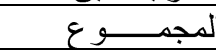 \\
\hline
\end{tabular}

تبين من دراسة أرضيات المساكن موضع الدراسة لأفــراد

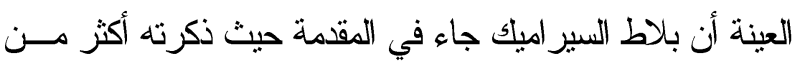

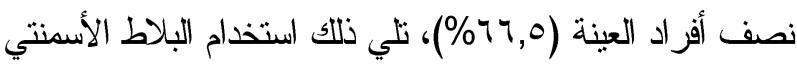

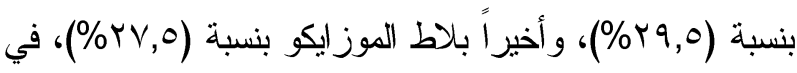

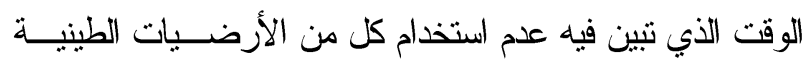

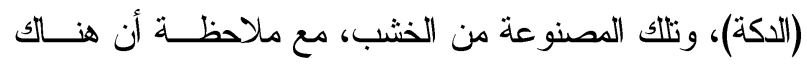
بعض المساكن تستخدم أكثر من نوعية داخل الوحدة السكنية. 
كل من لمبات الفلورسنت، ولمبات التوهج العاديــة حيـــ

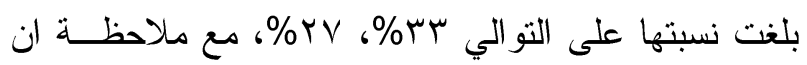
بعض المساكن المدروسة كانت تستخدم أكثر من نوعية من من

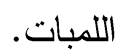

\section{ر- جودة التهوية داخل المسكن:}

يتضح من النتائج البحثية أن أكثر من ثلثي المبحوثنـات

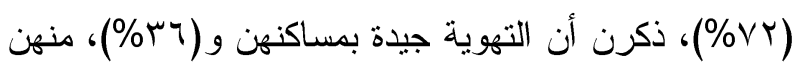

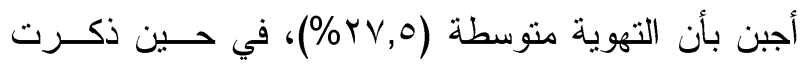

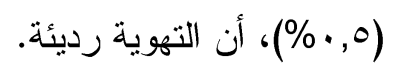

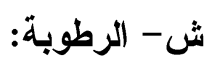

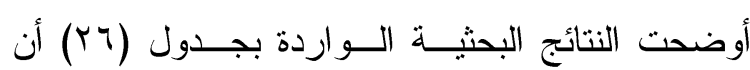

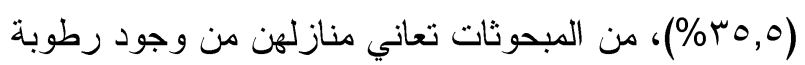

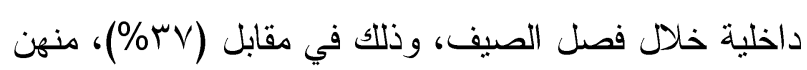
ذكرن ارتفاع رطوبة مساكنهن خلال فصل الثتاء.

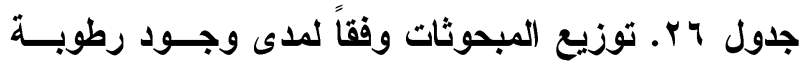

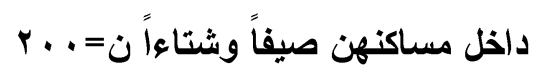

\begin{tabular}{|c|c|c|c|c|}
\hline \multicolumn{2}{|c|}{ لا يوجد } & \multicolumn{2}{|c|}{ يوجد } & التواجد \\
\hline$\%$ & العدد & $\%$ & العدد & فُصول السنة \\
\hline$T \leqslant, 0$ & 1199 & $r 0,0$ & $V_{1}$ & في الصيف \\
\hline זיד & $1 Y 4$ & rv & $V \varepsilon$ & في الثتاء \\
\hline
\end{tabular}

ت - الاتصال بالمر افق العامة:

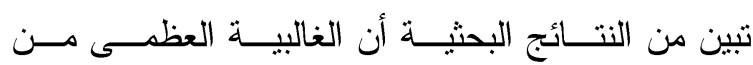
المبحوثات ذكرن أن مساكنهن متصـــلة بثــبكة الميــاه العمومية(9 9\%)، وذلك باستثاء منزل و احد فقط وذلك دكان من جملة المساكن موضع الدراسة.

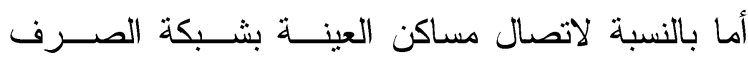

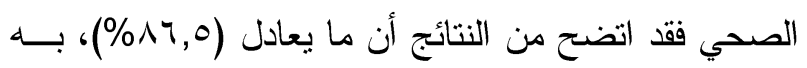

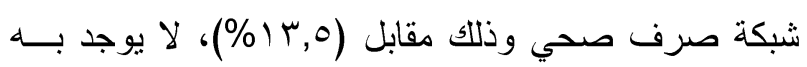
تلك الثبكة.

وفيما يتعلق باتصال المساكن موضع الدراسة بكل مسن شبكة التليفون و الغاز الطبيعي فقد أوضحت النتائج البحثيــة
الألوميتال، وذلك مع ملاحظة إستخدام بعض المساكن لأكثر من مادة لتشطيب النو افذ. جدول \& ؟. توزيع المبحوثات وفقاً لنوعية دهان الحـو ائط

\begin{tabular}{|c|c|c|}
\hline$\%$ & العدد & الثنو عية. \\
\hline $4 ., 0$ & $|r|$ & دهان بلاستيك \\
\hline$r 9,0$ & 09 & دهان بالزيت \\
\hline 19,0 & rq & دهان الجير \\
\hline 1. & r. & غير مدهون \\
\hline 1,0 & $r$ & ورق حائط \\
\hline $1 \ldots$ & r... & المجمــــوع ع \\
\hline
\end{tabular}

ف- المطلات الخارجية:

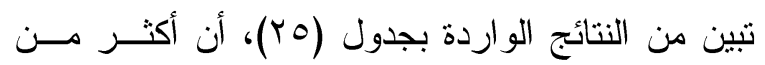

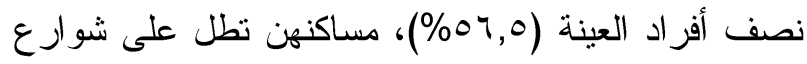

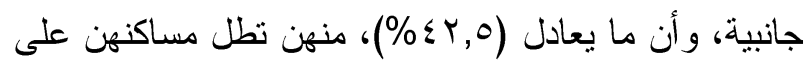

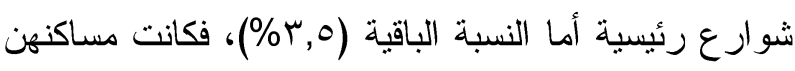
تطل على أراضي زر اعية أوترعة. جدول ه r. توزيع المبحوثات وفقــاً للمطـلات الخارجيــة

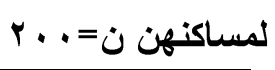

\begin{tabular}{|c|c|c|}
\hline$\%$ & العدد & المط \\
\hline 04,0 & $11 \pi$ & شار ع جانبي \\
\hline$\varepsilon r, 0$ & 10 & شار ع رئيسي \\
\hline$r, 0$ & $\mathrm{~V}$ & \\
\hline
\end{tabular}

ص- الإضاءة الطبيعية:

أوضحت النتائج البحثية أن الإضـاءة الطبيعية كانت جيدة الإهناءة

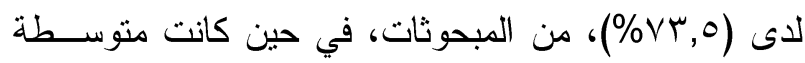

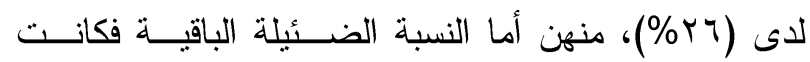

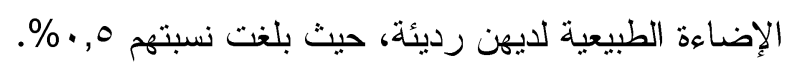
ق - مدى الاتصال بشبكة الكهرباء:

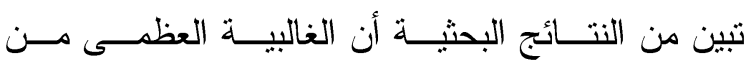

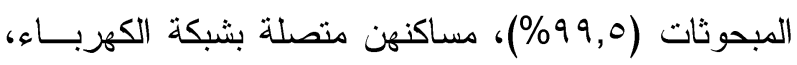
في حين أن مسكن واحد فقط غير متصل بنلاك الثبكة.

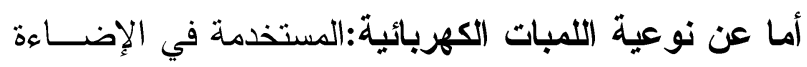

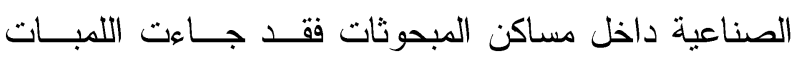

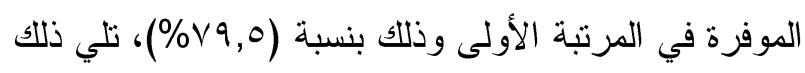




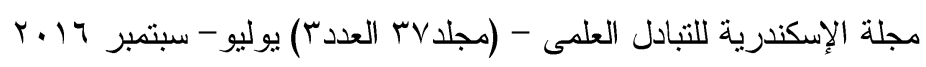

ض - مواصفات المسكن الجيد: أثنارت النتائج إلى أن نسبة المبحوثات اللائي يرغبن في

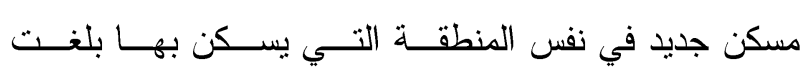

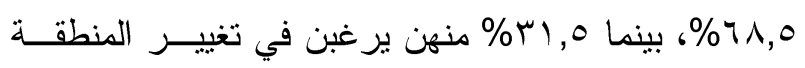

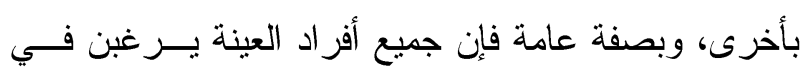
تغيير مسكنهن بآخر جديد.

أما عن مو اصفات المسكن الجديد مــن وجهــة نظــر المبحوثات فقد تبين ما يلي:

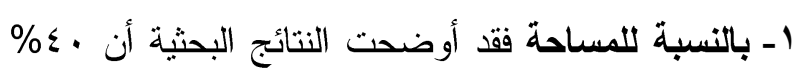

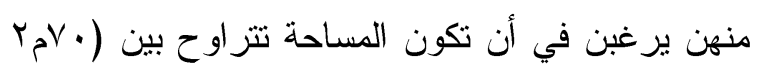

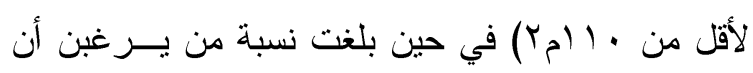

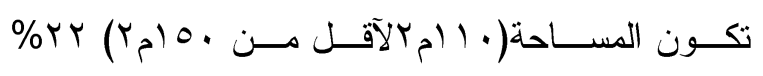

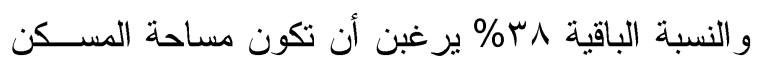
. 0.

r- بالنسبة لعدد أدوار المسكن فقد تبين من النتائج البحثية أن سب\% من المبحوثات برغبن في مسكن مستقل دور

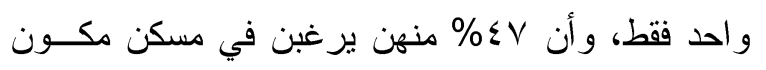

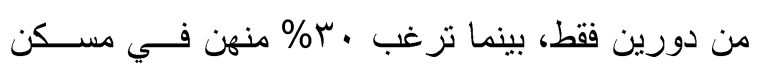
متعدد الطو ابق.

r- بالنسبة لعدد الغرف المكونة للمسكن فقــد نتـين مسن

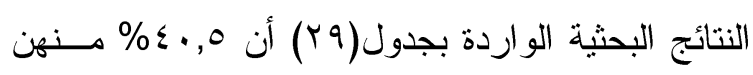
ترغب في عدد غرف يتز اوح من (r-r غرفــة)، وأن

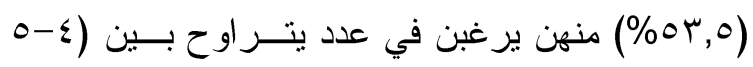

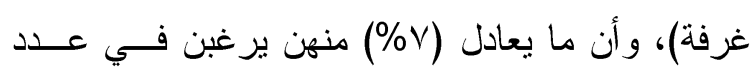
غرف يتراوح بين (ا- لأكثر من ^ غرفة).

ع-وبالنسبة لمطلات المسكن المرغوب فقد جاء الطريـق

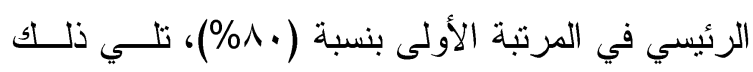

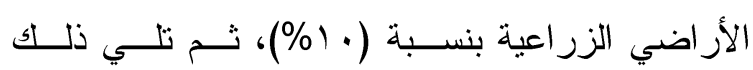

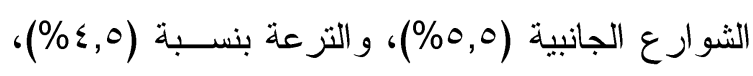
وذللك من جملة المبحوثات أفراد العينة.
أن (r^\%)، من تلك المساكن غير متصلة بالثبكة الأرضية للتليفونات، وأن (1 إ\%)، فقط منها متصلة بتلأك الشبكة، أما فيما يتعلق بشبكة الغاز فإن جميع أفراد العينة ذكرن عــدم توفر تلك الخدمة بمساكنهن. خ- طرق التخلص من النفايات المنزلية:

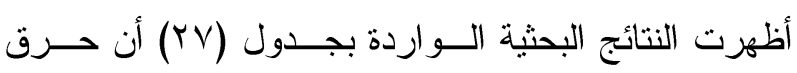

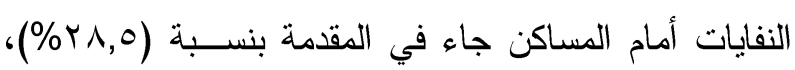

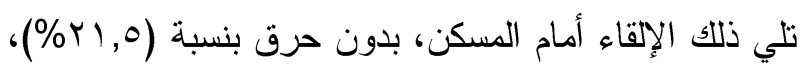

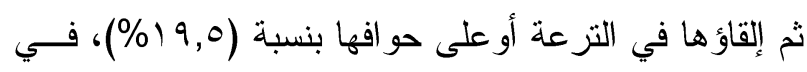

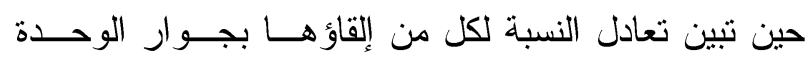

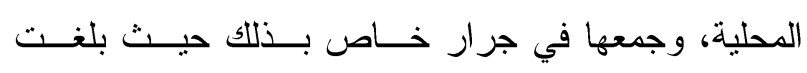
(\%V,0) جدول rV. توزيع المبحوثات وفقاً لطريقة تخلصهن مسن

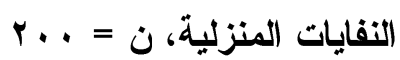

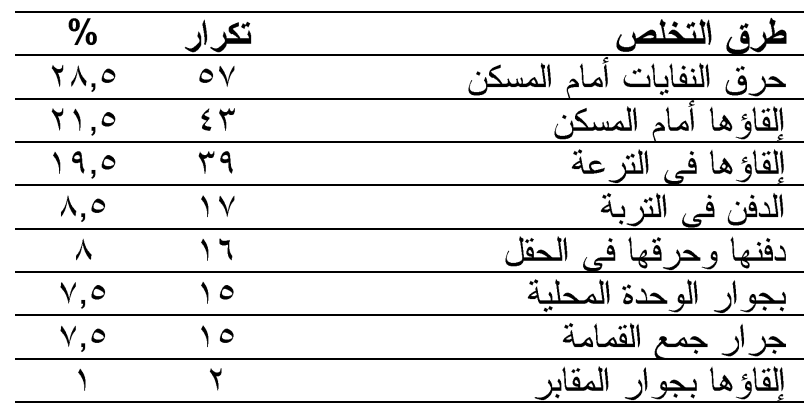
ذ- الرضا عن المسكن: أوضحت النتائج البحثية الواردة أن أكثر مــن ثلثـي

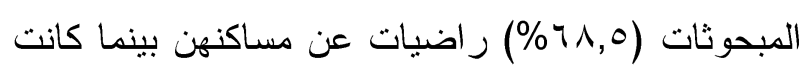

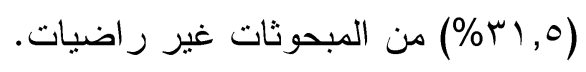
وفيما يتصل بالأسباب التي ذكرتها المبحوثات اللائي أفدن رضائهن عن المسكن فقد أمكن حصرها فيما يلي: صغر مساحة المسكن و الازدحــام الحجـري

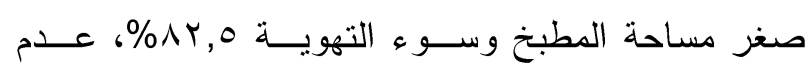

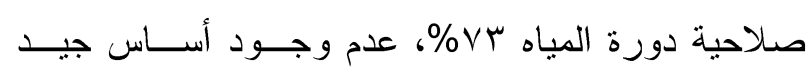

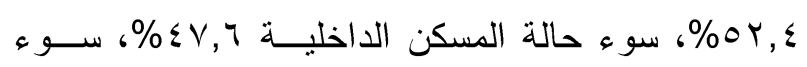
أرضية المسكن . \%\%. 


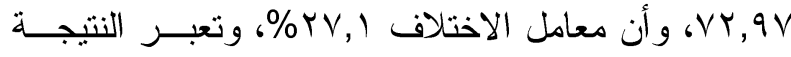
السابقة عن عدم التجانس بالنسبة لحالة الدسكن بين أفــراد

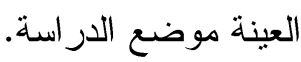

العلاقات الارتباطية بــين المتغـــــات البحثيــة المســتقة

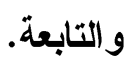

العلاقات الإرتباطية بين كل من المتغيـرات المسـنقلة

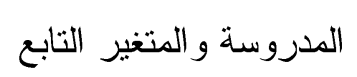

أشتارت نتائج التحليل الحصائى باستخدام معامل الأرتباط

$$
\text { البسيط (بيرسون ) جدول (•r) أن: }
$$

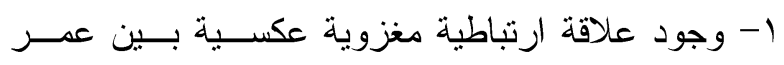
المبحوثة كمتغير مستقل وبين بيئة وحالة المسكن كمتغير

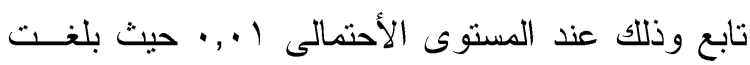

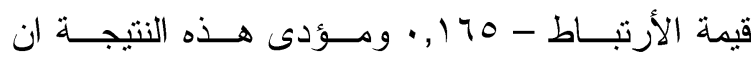

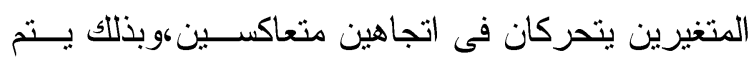
رفض الفرض الصفرى و الذى ينص على أنه (لا نوجد

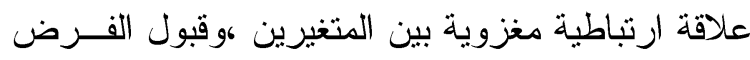
النظرى و الذى ينص على أنه (توجد علاقــــة ارتباطيـــة عكسية بين المتغير المستقل المدروس و المتغير التابع ).

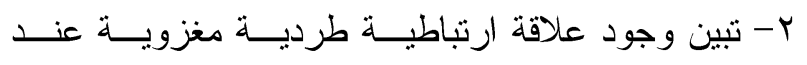

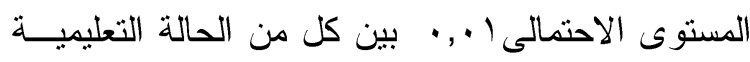

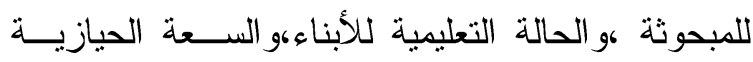

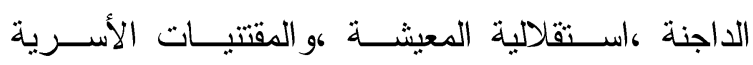

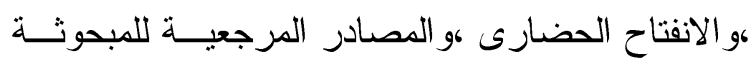

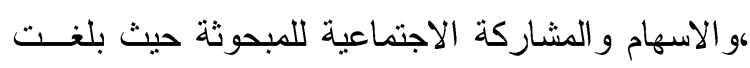

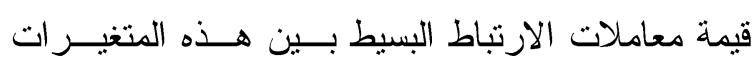

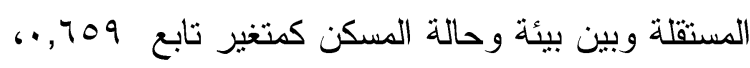
وبذلك يتم رفض الفرض الصفرى ويتم قبول الفـرض كلئل النظرى و الذى ينص على (أنه توجد علاقـــة إرتباطيــة

\begin{tabular}{|c|c|c|}
\hline$\%$ & العدد & الفئات \\
\hline$\varepsilon \cdot, 0$ & NI & r-r غر فة \\
\hline or, o & $1 . \mathrm{V}$ & ع- مغرفة \\
\hline$\varepsilon, 0$ & 9 & 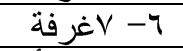 \\
\hline 1,0 & $r$ & ^ غرف فأكثر \\
\hline $1 \ldots$ & r... & المجموع ع \\
\hline
\end{tabular}
طردية بين هذه المتغيرات المستقلة و المتغبر التابع).
هـبالنسبة لمادة الطلاء فقد جاء الدهان الزيتي في المرتبة الأولى بنسبة (بVY\%)، تلي ذلائك الطلاء البلاستيك بنسبة

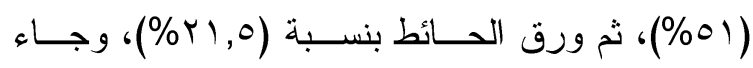

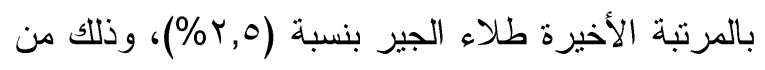

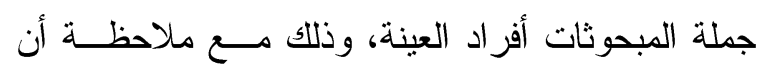
بعض المبحوثات ذكرن أكثر من مادة طلاء.

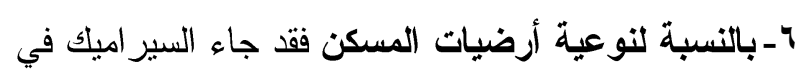

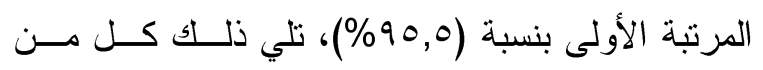
الخشب و البلاط بنسبة ضئيلة، جدول (· (r).

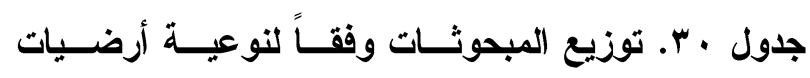

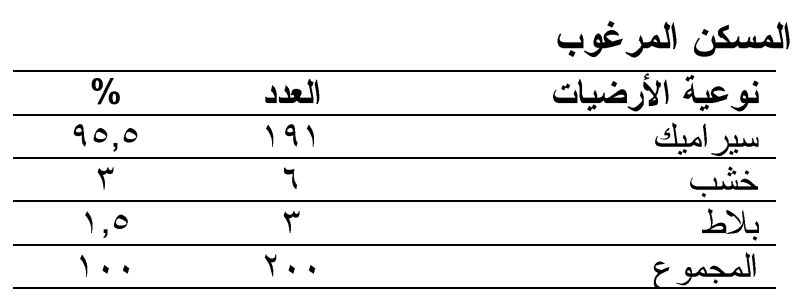

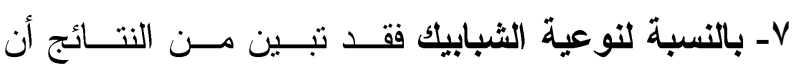

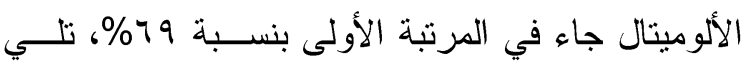

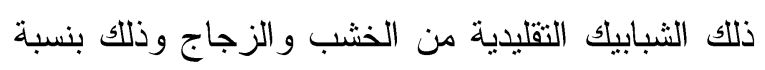

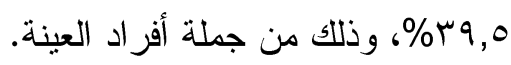

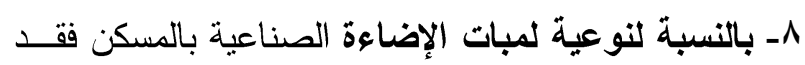

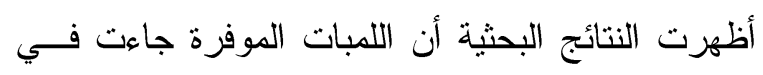

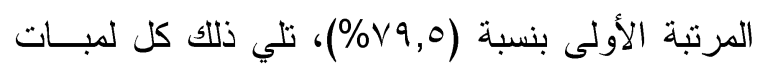

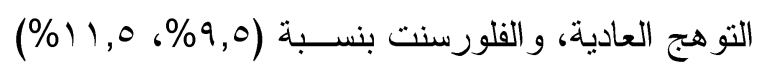
لكل منهما على التو الي، وذلك من جملة أفراد العينة.

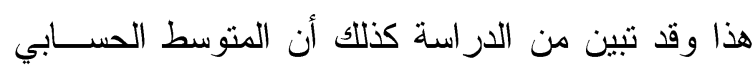

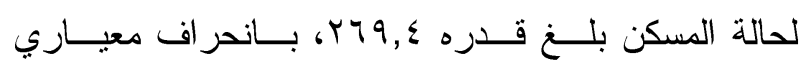


جدول · ·r. العلاقات الارتباطية بين المتغيرات المستقلة المدروسة والمتغير التابع

\begin{tabular}{|c|c|c|c|}
\hline المغنوية & معامل الارتباط البسيط & المتفير المستقل & s \\
\hline *** &., 170 & عمر المبحوثة & 1 \\
\hline- & $\cdot, \cdot, \leqslant 9$ & عمر زو ج المبحوثة & $r$ \\
\hline$* *$ &., $1 \vee 0$ & الحالة التعليمية للمبحوثة & $r$ \\
\hline- &., 117 & الحالة التتعليمية لزو ج المبحوثة & $\varepsilon$ \\
\hline- &.,$+\mathrm{TI}$ & الدخل السنوى & 0 \\
\hline *** & .,YTI & استقلالية المعيشة & 7 \\
\hline$* *$ &.,$Y 04$ & المتنتيات الأسرية & $\mathrm{v}$ \\
\hline$*$ &., 109 & الأدوار التى تمارسها المبحوثة & $\Lambda$ \\
\hline$* *$ & $\cdot, 1 \wedge \wedge$ & الحالة التتعليمية لأبناء المبحوثة & 9 \\
\hline *** & $\cdot, r \leqslant q$ & الأنفتاح الحضارى & 1. \\
\hline$* *$ & $\cdot, \mathrm{V} \backslash \mathrm{A}$ & المصادر المرجعية للمبحوثة & 11 \\
\hline *** &., .709 & الإسهام و المشاركة الإجتماعية للمبحوثة & Ir \\
\hline * & $\cdot, 1+9$ & السعة الحيازية الزر اعية & $1 \pi$ \\
\hline * & $\cdot, 1 \leqslant 9$ & امتلالك المعدات والآت الزر اعية & $1 \leq$ \\
\hline 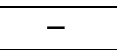 & $\cdot, .71$ & السعة الحيازية الحيو انية & 10 \\
\hline * * & $\cdot, 1 \wedge \varepsilon$ & السعة الحيازية الداجنة & 17 \\
\hline * & $\cdot, 111$ & المتغير ات التكنولو جية & IV \\
\hline
\end{tabular}

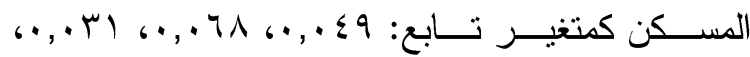

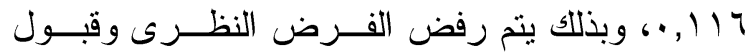
الفرض الصفرى والذى ينص على أنه (لا توجد علاقة

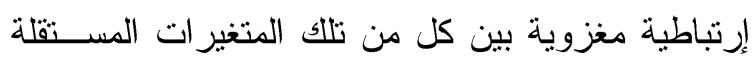

$$
\text { و المتغير التابع ). }
$$

\section{المــراجـع}

إبر اهيم سعد الدين محرم ا...r، التتمية الريفية- مركــز عمـر لطفي للتنريب التعاوني الزر اعي- الإنماعيلية.

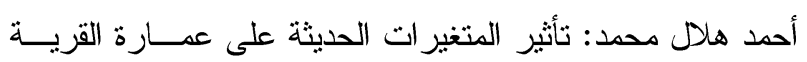

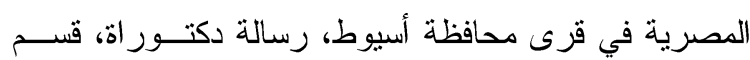

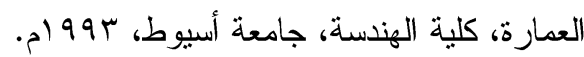

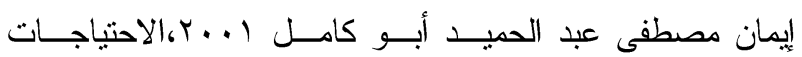

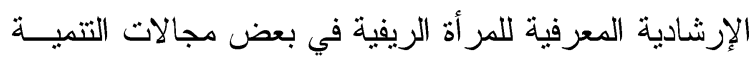
الأسرية بقرية محلة منوف مركز طنطا محافظة الغربية.

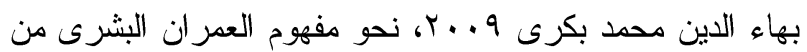

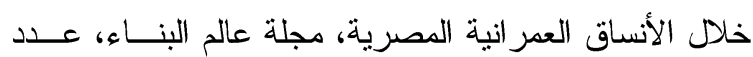

r- كما اتضح كنلك من نتائج التحليل الأحصائى ان هنالك علاقة ارتباطية مغزوية عند المستوى الأحتمالى ه.,.

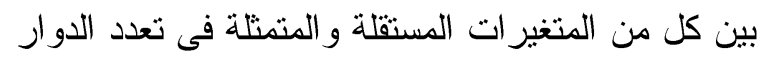
التى تمارسها المبحوثة، السعة الحيازيــة المزرعيــة،

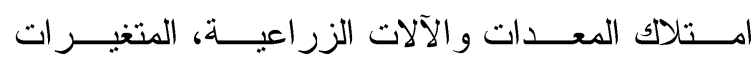
التكنولوجية حيث بلغت قيمة معامل الأرتباط البسيط بين نلك المتغيرات المستقلة كل على حدى وبين بيئة وحالة

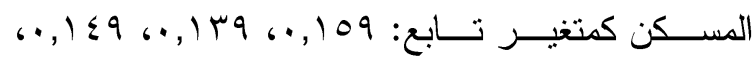
111, ا... وبذلك يتم رفض الفرض الصفرى ويتم قبــول

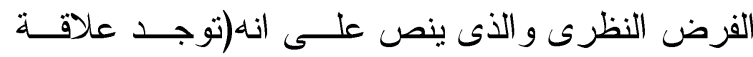

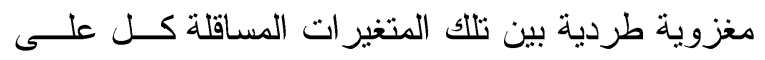
حدى و المتغير التابع).

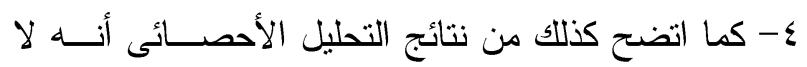
توجد أية علاقة ارتباطية ذات دلالة معنوية بين كل من

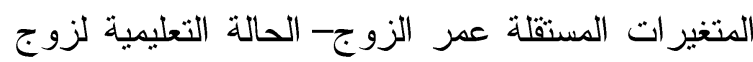

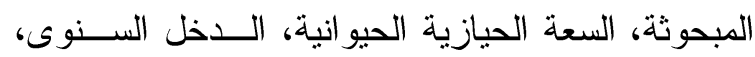

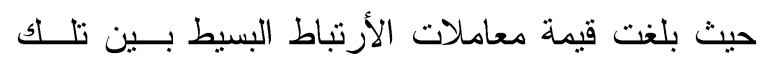

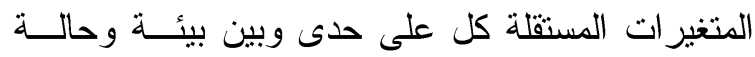


الفيوم- المؤتمر الحادي عشر للإحصاء و الحسابات العلميــة و البحوث الاجتماعية و السكانية- جامعة عين شمس - المجلد

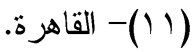

محمد عبد الوهاب جاد الرب 19991، دراســـة الأســر الريفيــة

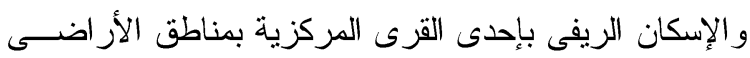
المصرية المستصلحة، قرية الناصر بمنطقة شمال التحرير - لإيل

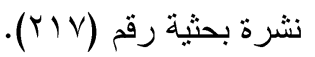

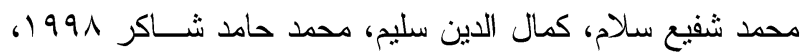

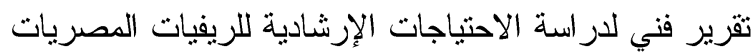

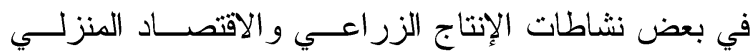

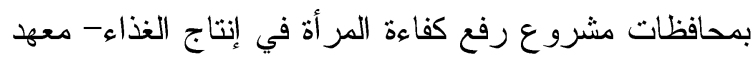
البحوث و الإرشاد الزر اعي و التتمية الريفية- مركز البحوث

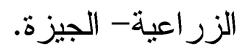

محمد محمود بركات 999 1، در اسة لبعض عناصــر التركيـبـ الديموجر افي للقرية المصرية- رســالة ماجسـتير - كليــة الزر اعة- جامعة عين شمس. مصطفى ابر اهيم الحفناوى، المسكن الريفى و التخطيط العمر انـى

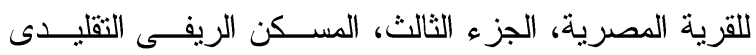
و الحديث، اكاديمية البحث العلمى، الهيئة العامة لبحوث البناء و الاسكان و التخطبط العمر انى، القاهرة، . ـ191.

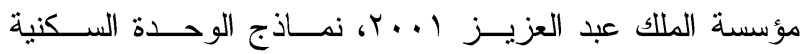
www.kaf.org.so - pdetails هشام جلال الثيمى 999 1، تقنيات أساليب إنشاء و إدارة برنامج

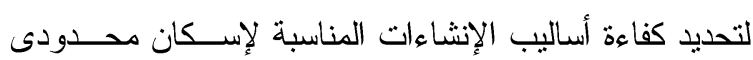

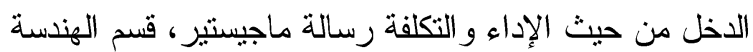
المعمارية، جامعة الإسكندرية.

هنا محمد سعد · ( • r، مفاهيم المشاركة المجتمعيــة و اهيتهــا، http:/or .m.wikipidia.org ويكيبديا الموسوعة الحرة وله

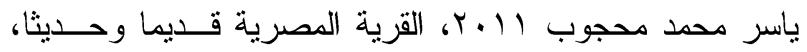

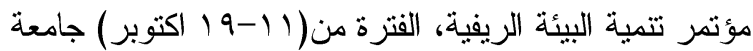
عين شمس.
حسن محمد الفارس 9 . . ب، المسكن الريفى بــالمغرب، جامعــة

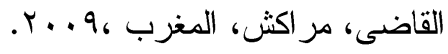

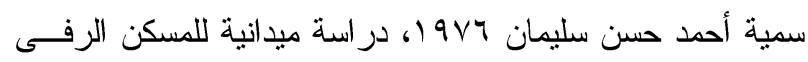
و إمكانيات تحسنه بعض قرى محافظـــة المنوفيـة، رســالة

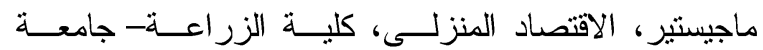

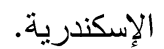

سهير على قنديل 999 1، العو امل المؤثرة فى تحقيق الإستمر ارية

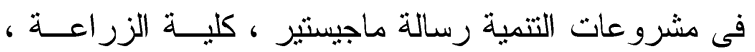

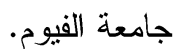

صفاء فؤاد توفيق ع 99 (، در اسة الاحتياجات التدريييـة للمــر أة

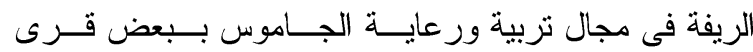

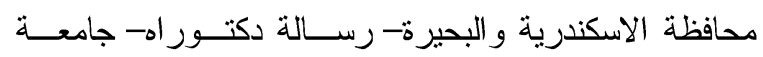
الأسكندرية.

عبد الحليم أحمد مزربان، عبد الصبور أحمد عبد الوهاب 999 19 199

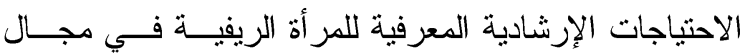

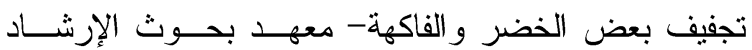
الزر اعي و التنمية الريفية- نشرة بحثية( الع)- الجيزة. عثمان عمر المحمد || • Y، الإنفتاح الفكرى ومدلو لاته ، شـبكة

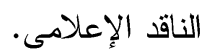

عفت عبد الحميد أحمد 1997، تلتشيط وتدعيم المــرأة الريفيـة

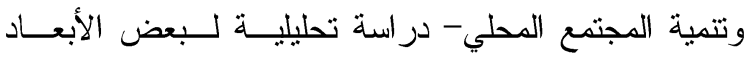

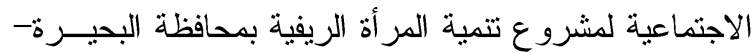
رسالة دكتور اه- كلية الزر اعة- جامعة القاهرة. علية محمود عبد الهـادى بلو9 ا، حركــة الإنســان وعلاقتهــا بالصميم الداخلى للمسكن المعاصر رسالة ماجيسـتير، كليــة الفنون الجميلة، القاهرة.

فاروق عباس حيدر ؟991، تخطيط المدن و القــرى- الطبعــة

$$
\text { الأولى - منشأة المعارف- الإسكندرية. }
$$

فؤ اد كمال سليمج99 99 (، مطلوب رعاية متكاملة للمر أة الريفية عن

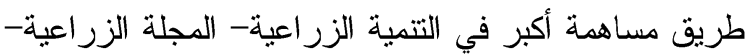
مؤسسة دار التعاون و النشر - العدد (ع ())- القاهرة. محمد أحمد عبد القادر 1 ...r، دراسة لتحديد درجـة مشــاركة

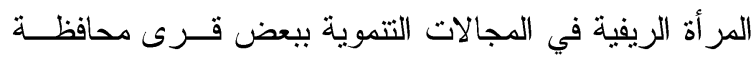




\title{
ABSTRACT \\ The Effect of the Community, Humanitarian, Urban and Technological Changes for the Rural Housing in El Gharbia Governorate
}

\author{
Somia A. Hasan, Magda K.Gaballa, Afaf M.Gibran, Mai A. R. El-Tatawy
}

The rural housing is considered an indicator for the economic level and the environmental situation among villages and the extent of variation of services among them, the environmental behavior of the villagers in terms of the protection of land resources and lack of expansion in building on agricultural land and the use of manufactured building materials instead of destroying agricultural land.It also refers to the health level of family members by protecting them from creepy-crawly and bacterial pollution according to the cleanliness of housing and taking into account the health conditions in its design, and the development in the form of housing is determined by the human position, which varies upon the difference of civilization to which it belongs that includes a number of social, economic and cultural variable factors, besides the housing with its form and design represents the social way of life in any community and reflects the level of living of its members as well as it expresses directly about its customs and traditions.

And if it is difficult that the house is suitable healthy, socially and economically for different categories of people in the city, it is more difficult in the countryside because it is known that it is affected by many societal and technological factors that make the individuals accept to live in particular houses that may be in favor of the development of the individual and the community and on the other hand may not be in the their favor.

This research focused mainly to identify the community, humanitarian, architectural and technological changes affecting rural houses in a village of Tanta in Gharbia Governorate.

The exploration data was collected by using a questionnaire form with personal interview on a sample of 200 Surveyed persons from the total that represents $10 \%$ of the housing in Mehalet Menouf village Gharbia Governorate, the statistical analysis of the data has been corried out in each of the reiterating, the percentage, the arithmetic mean, the standard deviation and the Simple correlation coefficient

The findings indicate that there is a decent relational relationship at the potential level of 0.01 between the environment and the state of residence as a dependent variable and each of the independent variables represented in: the surveyed age, the educational status of each of the surveyed and her children, poultry possessory size and independence of living.

It has also noticed large discrepancy between the respondents with respect to each of the variables related to each of the independence of living, agricultural and animal tenancy and home figurines and it turned out that there is great variation with respect to the direction of respondents towards healthy residential environment. 